Est Ag 44 (2009) 375-423

\title{
Dos versiones castellanas del Catecismo de Calvino
}

Cuando se cumplen cinco siglos del nacimiento de Juan Calvino, aparece la ocasión de reflexionar sobre su Catecismo, pero no tanto en la obra original francesa, sino en las versiones castellanas con las que algunos españoles pretendieron dar a conocer el pensamiento de aquél a quien consideraban guía espiritual. Son versiones del catecismo breve, escrito para divulgar su pensamiento, a diferencia de los otros escritos catequéticos de Calvino en los que aparecen sus criterios de forma amplia y razonada.

Tengo noticia de tres versiones al castellano, pero la sospecha es que una de ellas, que no he podido consultar, no se trata en realidad de una traducción del catecismo, sino de otra cosa, a pesar de que haya quien lo diga así. Por consiguiente, lo mejor es comenzar por dar noticia de las tres versiones, para después descender a los matices y precisiones.

Es preferible seguir el orden cronológico en que éstas vieron la luz.

La primera versión lleva por título Catechismo. A saber es formulario para instruir los mochachos en la Christiandad: Hecho a manera de Diálogo, donde el Ministro de la Yglesia pregunta, y el mochacho responde. En la obra no consta ni en portada, ni en parte alguna de ella, el lugar de edición, ni la imprenta en que se ejecutó. Es de 1550.

La segunda versión tiene este otro título: Sumario Breue de la Doctrina Christiana hecho por via de pregunta, y respuesta, en manera de coloquio, para que assi la aprendan los niños con más facilidad, y saquen della mayor fructo. En que también se enseña como se han de aprovechar della los que la leyeren, Venecia, Pietro Daniel, 1556.

La tercera versión varía algo el título con relación a la primera; está titulada así: Catecismo que significa forma de instrucion: que contiene los principios de la religion de Dios, vtil y necessario para todo fiel Christiano. Compuesta en manera de dialogo donde pregunta el maestro, y responde el discipulo, Ginebra, Jean Crespin, 1559. 
Tras esta primera noticia, voy a centrarme en la segunda versión, para descartarla de este estudio. Una elemental razón de ese descarte es no haber podido disponer de copia de ella. Pero hay más razones. De ella dice J. R. Guerrero:

«Esta obra del reformista español Juan Pérez no fue impresa en Venecia, ciudad que utilizaba para desorientar a las autoridades, sino en Ginebra. Aunque en el colofón se dice: "fue visto y aprobado este librico por los muy reverendos señores de la Inquisición de España", es falso. Esta Doctrina se parece mucho a la de Calvino»1.

La última afirmación de que únicamente se parece a la de Calvino refuerza la impresión de que en realidad no lo es y se trata de otra cosa. El título no se parece, excepto en el detalle de las preguntas y respuestas. Por otro lado, la falsificación del lugar de impresión no tiene nada de extraño en aquellos tiempos crudos, en que la penetración de la enseñanza no católica encontraba grandes dificultades en España. No tiene nada de extraño que aparezca en el colofón una frase que induce a error, para ver si de esta forma pasaba sin mayores problemas ${ }^{2}$.

Descartada esta obra, centro el estudio en las otras dos. Caso de que ésta fuera también una versión del Catecismo de Calvino, dispondríamos de tres versiones a lo largo de la década: 1550,1556 y 1559. Al menos disponemos de dos, al comienzo y final de la misma.

\section{LA VERSIÓN DE 1550}

La portada completa de la versión de 1550 es: Catechismo. A saber es formulario para instruir los mochachos en la Christiandad: Hecho a manera de Diálogo, donde el Ministro de la Yglesia pregunta, y el mochacho responde. Transladado de Frances en Español. Eph. I. El fundamiento de la Yglesia es la doctrina de los Prophetas y Apóstoles. 1550.

1 J. R. Guerrero, Catecismos de Autores Españoles de la primera mitad del siglo XVI (1500-1559), en Repertorio de Historia de las Ciencias Eclesiásticas en España, II, Salamanca, (1971), 253.

${ }^{2}$ El mismo Calvino no desdeñó emplear este sistema de la falsificación, si con ello se lograban sus propósitos de difusión: «Calvino ideó publicar libros que pasaban por católicos, como La manera de hacer rezar a las iglesias francesas, que llevaba en la cubierta la frase: "impreso en Roma, por mandato del Papa", y que, editado en Estrasburgo, era obra de su mano»: D. Rops, Historia de la Iglesia de Cristo, Madrid, Los Amigos de la Historia, 1970, v. VI, La reforma protestante, 315. 
La descripción detallada de la obra es como sigue:

$8^{\circ}$.- A-G ${ }^{4}, H^{2}$.- (en sig. señala en todos los cuader.: $\mathrm{A}^{5}, \mathrm{~B}^{5} \ldots$...). Paginada: 117 p.- Erratas en pag. 62 (por 61).- Reclamos en p. pares y signaturas en p. impares.

P. 1.- Portada: Catechis |mo. [Dentro de marco tipográfico] | A saber es formulario | para instruir los mochachos en la Chri- | stiandad: Hecho a manera de Dia- | logo, donde el Ministro de | la Yglesia pregunta, y | el mochacho re- | sponde.| Transladado de Frances en Español.| Eph. I.| El fundamiento de la Yglesia es la doctri- | na de los Prophetas y Apóstoles. | 1550.

P. 2.- Blanco.

P. 3-7.- Al muy Illustre Señor... A viii de Abril. M. D. L.

P. 7-8.- Epístola del Avctor al Lector.

P. 8.- [Nota metodológica] La manera desta instruction...

P. 9- 115.- De los artículos de la fe, de los diez mandamientos, de la oración, de la palabra y de los sacramentos.

P. 117.- Correction de las faltas principales de la impression.

De esta versión de 1550, Guerrero afirma lo siguiente:

«Se trata de la traducción castellana del Catecismo de Calvino que fue enviada a España en sobres cerrados a gran número de personas de la aristocracia. A. Palau y Dulcet dice que se trata del Catecismo de Calvino vertido sin modificaciones al castellano por Juan Pérez (t. XIII, 109). Dudamos que haya sido Juan Pérez el traductor, ya que su huida a Ginebra no tuvo lugar hasta $1555{ }^{3}$.

Por su parte, M. Menéndez Pelayo dice:

«Además de este catecismo ${ }^{4}$, debió de componer Juan Pérez otro, que en los Indices expurgatorios del Santo Oficio se prohíbe con esta advertencia: "Aunque falsamente dize que fue visto por los Inquisidores de España". El Sumario de doctrina christiana, que allí también se veda, no debe ser obra distinta del Breve tratado» ${ }^{5}$.

No tengo más remedio que señalar el error de Menéndez Pelayo al identificar dos obras que son nítidamente diversas.

La asignación por parte de Palau a Juan Pérez de Pineda es inexacta, por tanto; Guerrero expresa como duda lo que, en realidad, es una afirma-

\footnotetext{
3 GuERRERO, l.c., 254.

${ }^{4}$ Se refiere a Breve tratado de la doctrina Antigua de Dios i de la nueva de los hombres, impreso en 1560, pero que en realidad es la traducción castellana de la obra de Urbano Regio, como el propio traductor reconoce sin problema.

5 M. Menéndez Pelayo, Historia de los heterodoxos españoles, l. IV, c. X (Citado por la edición de Madrid, BAC, 1956, 108).
} 
ción rotunda, aunque inserte esta obra entre las de Juan Pérez de Pineda. Pero aún con mayor claridad lo había expresado Bataillon, de forma que no dejaba lugar a las cavilaciones:

«Ya en 1550 un refugiado desconocido, que había salido de España mucho tiempo antes, había publicado un Catecismo que era la traducción castellana del de Calvino, y en 1551 el peligroso librito se había mandado en sobres cerrados a gran número de personas de la aristocracia española, entre ellas el Almirante de Castilla» ${ }^{6}$.

Se trata de una traducción impresa en 1550, de la que el desconocido traductor no es desde luego Juan Pérez de Pineda. Es alguien que para esa fecha de 1550 ya llevaba unos años instalado en Ginebra, hasta el punto de que, como reconoce, tenía algunas dificultades para hacer una versión ágil.

Ya indiqué que la obra carece de pie de imprenta, y sólo consta el año de impresión. Sin embargo, no hay problema en identificar su procedencia. En el lugar indicado, en la nota 23, Bataillon se hace eco de la noticia del conato de difusión, introduciéndola como si se tratara de cartas, a algunos miembros de la aristocracia, y prosigue: «El ejemplar recibido por el Almirante venía de Valencia (A.H.N., Inquisición, li. 323, f. 154-1 y 156-1º). La Inquisición mandó examinar minuciosamente la escritura de los sobrescritos y la tipografía del volumen para tratar de descubrir la proveniencia de aquellos envíos». Hoy es posible asegurar la imprenta donde se confeccionó, en Ginebra, en la imprenta de Jean Crespin. La comparación con la edición francesa del Catechisme de Calvino, y con la edición castellana de 1559 , ambas salidas de esas prensas, no dejan lugar a dudas. Ahora bien, con vistas a su difusión por España, era natural que se eliminara el pie de imprenta, que pondría fácilmente en guardia a quien tomara en sus manos el libro y tuviera una cierta idea de lo que estaba sucediendo fuera de España. En cambio, el año de impresión era una información inocente, que no revestía problema.

Esta versión de 1550 tiene destacada la palabra Catechismo, de la portada por medio de una elegante greca tipográfica, a la que sigue el resto de la información. Dispone de dos preludios en las páginas iniciales: El primero es «Al mvy Illvstre Señor. El Señor. N. El transladador. Salud en nuestro Señor Iesu Christo» (p. 3-7)7. A este primer preludio sigue el titulado

\footnotetext{
6 M. Batalllon, Erasmo y España, México, Fondo de Cultura Económica, 1966, $2^{\mathrm{a}}$ ed., 704.

7 Dice Bataillon que «La fórmula inicial del prefacio, “Al muy illustre señor $\mathrm{N}$... el transladador", parece una dedicatoria en blanco a la cual se añadía el nombre de cada señor destinatario». A mi me parece que no es así, pues no hay más espacio en blanco que el inter-
} 
«Epístola del avctor al lector» (p. 7-8), breve, pero jugosa carta, de la que me ocuparé después. A dicha carta, casi a renglón seguido, se añade una nota metodológica extremadamente interesante, que igualmente merece ser comentada por su lado.

El traductor nos resulta desconocido, pero ofrece una serie de pistas sobre sí mismo en la primera carta preliminar. Afirma que es español («...la obligación que como Español les tengo...»); que ha huido («... yo procuré por todos los medios possibles de recogerme a esta ciudad...»; «...siendo yo llegado a la dicha ciudad...»), aunque no mencione, por prudencia e interés, el nombre de la ciudad de acogida; se ha sentido perseguido antes de verse obligado a huir («... librarme dentre las manos de aquellos que, hauiendose declarado enemigos de Iesu Christo, persiguen con tal vehemencia a los que dessean seguir sus pisadas...»; como era de esperar, no silencia el nombre genérico de sus perseguidores en España «por ser tan opprimida de los inquisidores de la fe». Además de reconocerlo en los datos de portada, asegura que traduce del francés «el Catechismo o formulario con que los ministros o predicadores desta yglesia enseñan e instruyen los mochachos»: aunque silencia el nombre de la iglesia a la que se refiere, la terminología coincide plenamente con la terminología ginebrina. La carta nuncupatoria, la primera de las dos, tiene fecha, como si de una carta personal se tratase: «A viii de Abril M. D. L.». No disponemos de un retrato completo del traductor, ni tampoco de su nombre, pero sí hay unos rasgos que permiten hacerse una idea de quién emprendió la primera traducción que nos ocupa.

Las preguntas están encabezadas por la indicación «Ministro», y las respuestas por la correspondiente «Mochacho», ambas con una amplia sangría. Hay un error en el reclamo de la p. 48 pues pone «Mochacho», cuando debería haber puesto «Ministro». En la p. 91 omite al comienzo la indicación de «Ministro».

La obra tiene ladillos. En ellos aparecen tres tipos de indicaciones: primero, la distribución de la materia en 55 domingos, de la que luego me ocuparé; después, en letra de cuerpo menor, breves indicaciones o titulillos sobre la materia de que trata el texto; en tercer lugar, también con letra menor, las referencias bíblicas a que remite, en las que apoya sus afirmaciones. (Omite, por error la indicación del domingo $13^{\circ}$; en el domingo $28^{\circ}$ señala el $21^{\circ}$; en el domingo $37^{\circ}$ señala el $27^{\circ}$ ).

lineal, y el tono de la redacción va más en la línea de una carta nuncupatoria que buscaba la protección de alguien, para que costease la edición; no se da el nombre del destinatario de tal carta nuncupatoria para no poner sobre la pista a los inquisidores. 
En el mismo título aparece sin ambages que ha sido traducida del francés. Aparecerán algunas ocasiones en que se comprueba que la traducción resulta dura, forzada. Pero quiero fijar la atención en la fe de erratas que figura en la p. 117. Parece que al hacerla, el corrector, o el traductor, ha bajado la guardia para detectar fallos. Así, comienza por aparecer la palabra «Correction» al inicio de la página; cuando remite a una errata en la p. 110 dice «en la Cotation», cuando antes ha escrito «Cotación»; pero todavía al remitir a dos erratas: la de la p. 80 precisa «... al postrero renglón...», y la errata que viene a continuación en la línea siguiente dice «au premier renglo...». La vigilancia ha cedido paso a la prisa o a la dejadez.

\section{LA VERSIÓN DE 1559}

Esta segunda versión estudiada, tiene otro título ya reproducido. La portada íntegra dice así: Catecismo qve significa forma de instrucion: que contiene los principios de la religion de Dios, vtil y necessario para todo fiel Christiano. Compuesta en manera de dialogo donde pregunta el maestro, y responde el discipulo. Sal. CXIX. La declaracion de tus palabras alumbra. Y da cumplimiento a los pequennos. Nvevamente impresso. Año de 1559.

Procede llevar a cabo la descripción pormenorizada de esta obra:

$8^{\circ}$.- A-N4.- Paginada: 181 p. Error en paginación 155 (en lugar de 164).

P. 1.- [Portada]: Catecismo | qve significa | forma de in- | strucion: que contiene los prin- | cipios de la religion de Dios, $\mathrm{v}$ - $\mid$ til y necessario para todo fiel | Christiano. | Compuesta en manera de dialogo don- | de pregunta el maestro, y responde el | discipulo. | [Grabado con dos adornos florales en forma de media luna; de cada uno de ellos emerge hacia el centro una mano, y ambas sostienen un ancla en cuya parte superior se enrosca una serpiente $]^{8}$. | Sal. CXIX. | La declaracion de tus palabras alumbra. Y | da cumplimiento a los pequennos. | Nvevamente impresso. | Año de 1559.

P. 2.- Blanco.

P. 3-14 .- A todos los amadores...

P. 14.- Deuter. VI...

P. 15.- Lo que en Suma contiene este libro de doctrina Christiana, es lo siguiente.

\footnotetext{
${ }^{8}$ La edición francesa de 1552, salida de la imprenta de Jean Crespin, tiene en la última página, además de una cita bíblica de Mt. 7, un ancla con una serpiente enroscada en la parte superior, como distintivo del impresor. A los lados de la marca de impresor figuran las palabras «Sacra» $\mathrm{y}$ «Anchora», dispuestas verticalmente.
} 
P. 16-20.- Formularios: el symbolo de la fe christiana, el decálogo, que son los diez mandamientos; la oración del Señor.

P. 21-139.- De los artículos de la fe; de los diez mandamientos; de la oración; de la palabra de Dios, y de los sacramentos.

P. 140-150.- Oraciones para antes y después de comer; Oraciones para cuando el Christiano se acueste y se levante de dormir.

P. 151-164.- La forma que se tiene en preguntar y examinar los pequeños antes de ser admitidos a recebir la Cena de nuestro Señor Iesu Christo.

P. 165-180.- Las oraciones y plegarias públicas que se hacen en la Yglesia; La forma de administrar los Sacramentos y de celebrar el Matrimonio; De cómo se han de visitar los enfermos; Una oración particular para los Christianos que están captivos debaxo de la tyrania del Antechristo; Una oración para quando es visitado el enfermo, y está en peligro de la vida.

Tiene ladillos, en los que, al igual que la edición descrita antes, se reúnen tres informaciones: la división de la materia para cada domingo, los títulos o síntesis que condensan la materia, y las referencias bíblicas en que se apoyan las afirmaciones del texto. (Falta, por error, la indicación del domingo $3^{\circ}$ ). La que se refiere a los domingos está con letra de cuerpo un poco mayor.

Hay reclamos en las páginas pares, mientras las signaturas figuran en las impares. Las intervenciones del «Maestro» y del «Discípulo» preceden a cada pregunta o a cada respuesta, y van marcadas con una amplia sangría.

Tanto en el apartado en que reúne los formularios al principio de la obra (p. 16-20), como cuando luego los repite en su lugar correspondiente al discurrir el texto, éstos aparecen con letra de cuerpo mayor que el resto, para destacarlos.

Al final del catecismo, los apéndices están redactados como texto seguido, salvo el titulado «La forma que se tiene en preguntar y examinar los pequeños antes de ser admitidos a recebir la Cena de nuestro Señor Iesu Christo», que aparece como diálogo entre el Maestro y el Discípulo, con las mismas sangrías e idéntico tipo de letra que el catecismo. En este caso, dada su brevedad, los ladillos sólo remiten a los textos bíblicos que fundamentan la doctrina.

En la p. 3 comienza una larga carta, a modo de prólogo, con el título de «A todos los amadores del Señor Iesu Christo y que biuen en la esperança de su venida, Salud». Tendré que volver sobre ella. En la portada constaba una cita bíblica; en la p. 14, al concluir la carta, figura otra cita íntegra:

«Deuter. VI. Estas palabras que yo te mando el dia de oy, (dize el Señor) estarán en tu coraçon, y contarlas has a tus hijos, y meditarás en ellas sentado en tu casa y andando camino: quando te acostares, y te leuantares». 
En la p. 15 aparece una especie de índice del conjunto del impreso: «Lo qve en suma contiene este libro de doctrina Christiana es lo siguiente». Da cuenta del contenido, que primero y principalmente tiene el catecismo propiamente dicho. A continuación aparecen otros contenidos:

- Oraciones para antes y después de comer.

- Oraciones para quando el christiano se acuesta y se leuanta de dormir.

- Vna forma de preguntar y examinar los pequeños discipulos de la doctrina, antes de ser recebidos a la sancta Cena del Señor.

- Las oraciones y plegarias públicas que se hazen en la Yglesia.

- La forma de administrar los Sacramentos y de celebrar el Matrimonio.

- De como se han de visitar los enfermos.

- Vna oracion particular para los Christianos que estan captiuos debaxo de la tiranía del Antechristo.

- Vna oracion para quando es visitado el enfermo, y esta en peligro de la vida.

La parte que se refiere al catecismo induce a un cierto error, porque, situada inmediatamente antes de los apéndices que he reseñado, tiene los siguientes tres epígrafes:

- Declaración breue y compendiosa de los articulos de la fe.

- Declaracion de los diez mandamientos de la ley.

- La oracion del Padre nuestro con su declaración.

Pero el índice olvida que el catecismo tiene una cuarta parte, la que se titula después - De la palabra y de los sacramentos. Pero esta omisión pasó inadvertida, y así hay que hacerlo constar.

No aparecen datos del traductor; esta versión sabemos que obedece sin discusión a la pluma de Juan Pérez de Pineda, y que está editada en Ginebra, Jean Crespin, 1559.

La constatación, en portada, de nuevamente impresa tiene el valor de recientemente impresa, en el lenguaje editorial del XVI, por lo que no hay que pensar en otra edición anterior ${ }^{9}$.

Comparándola aunque no sea más que en los datos ya apuntados con la versión anterior, hay que dejar constancia de un importante deslizamiento. La versión de 1550 constaba como un diálogo entre el Ministro y el Muchacho; pero la versión de 1559 señala que el diálogo discurre entre el Maestro y el Discípulo. La primera utilizaba la terminología en uso en la 254.

9 Sí hay otra edición posterior, seguramente de Amberes, 1596, según GUERRERO, l.c., 
sociedad teocrática de Ginebra; la segunda ha desplazado los términos hacia un lenguaje académico, escolar. El ministro ya no es el ministro o pastor que enseña y explica en el templo, sino el maestro, cuyo mundo es la escuela; y el muchacho o niño pasa a ser el niño escolarizado, o discípulo. Sin embargo, esto no es más que una falsa sensación, porque la lectura muestra que en absoluto se refiere al universo escolar, y tiene el mismo estilo eclesial que la versión anterior, a pesar del cambio de términos.

\section{El Catéchisme de Calvino}

Descritos los ejemplares, procede llevar a cabo un análisis en profundidad. Han aparecido ya algunos parecidos y diferencias, puesto que estas versiones no son réplica una de otra, sino que tienen como referencia la obra que el propio Calvino llevó a cabo. Por eso mismo, es un paso imprescindible conocer el modelo al que remiten, si bien no lo hagan de forma expresa, dado que en ninguna de las dos versiones castellanas aparece el nombre de Calvino por parte alguna. Era lógico, puesto que lo que pretendían era la difusión entre los españoles de la península -más algunos ejemplares que pudieran ser útiles a los que habían tenido que desplazarse al extranjero, especialmente a Ginebra-, con el convencimiento de que la sola mención del nombre de Calvino predispondría a muchos para su lectura. El omitirlo daba la posibilidad de que se leyese y, acaso, se aceptasen los planteamientos contenidos en la obra.

Juan Calvino (antes de ser latinizado, como era costumbre entre los intelectuales, su apellido era Cauvin) había nacido en Noyon en 1509. Después de estudiar leyes, siguiendo las indicaciones paternas, se orientó al estudio de los clásicos, hasta que empezó a reflexionar sobre las nuevas propuestas reformadas. Como era corriente entonces, obtuvo algunos beneficios eclesiásticos, aun siendo seglar. Primero en Orleáns (1528-29) y después en París, se puso en contacto con representantes de las ideas luteranas, que de alguna manera fue asimilando, especialmente el planteamiento radical de la corrupción absoluta de la naturaleza humana. En París en 1531, tuvo contacto y amistad con el rector, Nicolás Cop, y, tras el discurso de éste en la apertura de curso de 1533, ambos tuvieron que exilarse. Tras una serie de peripecias, pasando por Estrasburgo, llegó a Basilea en 1535. Allí encontró el tiempo y el reposo necesarios para dar forma a su pensamiento que plasmó en la primera edición de su obra más importante, la Calvini Institutio christianae religionis, cuya primera edición vio la luz en latín en Basilea, Oporin, 1536, un 
volumen de 520 p. en $8^{\circ 10}$. Más adelante, deseoso de que su pensamiento se difundiese por Francia, la editó en francés con el título Institution de la religion chrestienne, publicada en Estrasburgo, Ribel, 1539, con 436 p. en folio.

Tras una estancia de unos meses en Ferrara, en Italia (abril a junio de 1536), regresó con la idea de tornar a Estrasburgo, pero a consecuencia de la guerra, hubo de dirigirse a Ginebra. Allí Guillermo Farel protagonizaba la Reforma, y controlaba los resortes de la vida ciudadana. Cuando Calvino llegó a Ginebra, Farel lo acogió y promocionó como evangelizador. En septiembre-octubre de 1536 ambos, junto con otros teólogos, intervinieron en la disputa de Lausana frente a algunos teólogos católicos; Calvino salió reforzado con la aureola de un hombre valioso. Su puesto en Ginebra adquirió más y más importancia: reemplazó el culto católico, propuso una doctrina que tenía que ser aceptada por todos los ciudadanos, y se propuso la revisión de las costumbres. Para el primer punto no tropezó con demasiados problemas. En cambio, tropezó con la resistencia de los burgueses de Ginebra, así como otros sectores de la ciudad que se resistían a aceptar las exigencias en cuanto a renovación de costumbres. Comenzaron los alborotos y se vio en la necesidad de abandonar la ciudad (abril de 1538).

Como profesión de fe sacó a la luz la obra que en francés se titula Instruction et confession de foy, dont on use en l'Eglise de Geneve, [Ginebra], [Wigand Koeln], febrero de 1537. Esta misma obra la publicó en latín al año siguiente con el título de Catechismus, sive Christianae religionis institutio, Basel, Robert Winter, 1538. Distribuida en 33 capítulos, sigue bastante de cerca el mismo plan que la obra magna, si bien aborda las cuestiones con mayor brevedad que en aquélla11. El doble título puede inducir a error ${ }^{12} \mathrm{y}$ considerar que se trata de dos obras diversas ${ }^{13}$; también existe otro equívo-

10 La epístola preliminar que dirige al rey de Francia, Francisco I, está fechada en agosto de 1536. La obra apareció en la Feria de Pascua de 1536, y constaba de seis capítulos.

11 Esta obra, a partir de la edición latina, la tradujo al castellano Francisco de Enzinas, con el seudónimo de Francisco de Elao, en la que alteró el título por el siguiente: Breue y compendiosa institucion de la religion christiana, neçessaria para todos aquellos que con iusto titulo quieren usurpar el nombre de Christo. Escripta por el doctor varon Francisco de Elao, a ruego de un amigo y hermano suio en Christo, Topeia, impressa por Adamo Corvo, 1540 [falso pie de imprenta, pues en realidad fue impresa en Anvers, a comienzos de 1542]. Ver GuERRERO, l.c., 234-235.

12 En B. LlorCA y otros, Historia de la Iglesia Católica, III. Edad Nueva, Madrid, BAC, 1960, 685, nota 19 se dice: «Véase el texto en Corpus Ref., Opera Calvini, V, 313: Catechismus, sive christianae religionis Institutio. La primer edición se hizo el Basilea, 1538. En 1541 se hizo una segunda edición, mejorada, que es su segundo catecismo (Ibid., XXII, 5s)».

13 A. Zillenbiller - M. VIal (eds.), Instruction et confession de foy dont on use en l'Eglise de Geneve. Catechismus seu christianae religionis institutio Ecclessiae Genevensis, en Ioannis Calvini Scripta Ecclesiastica, v. II, Genève, Librairie Droz, 2002. (Edición crítica). 
co, porque el hecho de titular a ésta en latín Catechismus lleva en más de un caso a identificarla con la otra obra que sigue.

Expulsado de Ginebra e instalado en Estrasburgo, se hizo cargo de una pequeña comunidad de origen francés, a los que dirigió. Por entonces parece que haya que situar la redacción del Catéchisme. A pesar de todo, las informaciones no son enteramente exactas, puesto que una información, que parece segura ${ }^{14}$, pero no contrastada, afirma que fue redactado en francés en 1536 y fue publicado al año siguiente. Sin embargo, parece que la redacción original de su Catecismo no fue en francés, sino en latín, pues, de hecho, apareció en latín en 1537 (Por lo tanto, aún en la primera estancia en Ginebra). Esa misma información afirma que en Ginebra, en 1542 lo publicó en francés, reemplazado por una nueva versión, con 373 preguntas, que sería la forma definitiva. Existe un dato destacable, pero de fecha imprecisa en relación con el Catéchisme. Se trata de la afirmación que el propio Calvino hace en la Institutio (libro IV, cap. XIX, 13), cuando habla de la confirmación católica: «Una excelente manera de instrucción sería que hubiese un formulario o catecismo propiamente dedicado a esto, que contuviese y explicase familiarmente los puntos principales de nuestra religión, los cuales la Iglesia universal sin distinción alguna debería confesar; y que el niño, hacia los diez años se presentase a la Iglesia para hacer confesión de su fe; que fuese interrogado sobre cada punto y respondiese de ellos; y que confesase en presencia de la Iglesia la verdadera, pura y única fe, con la que todo el pueblo cristiano de común acuerdo honra a Dios» ${ }^{15}$.

Una edición consultada, ligeramente modernizada, da el título de Le Catéchisme de l'Eglise de Genève, 1545, c'est-à-dire, le formulaire d'instruir les enfants en la Chrétienté, fait en manière de dialogue, où le Ministre interrogue et l'enfant répond (pero no señala ni el lugar de edición ni la imprenta); otra edición consultada ha sido la que hizo en Ginebra, en la imprenta de Jean Crespin, datada en 1552: Catéchisme. C'est a dire, le formulaire d'ins-

\footnotetext{
14 Procede de una fuente calvinista, y se localiza en internet a propósito de la Fête de Jubilé du Calvin para el año 2009.

15 Citado por Institución de la religión cristiana, traducida y publicada por Cipriano de Valera en 1597. Reeditada por Luis Usoz y Rio en 1585. Nueva edición revisada en 1967, Buenos Aires - Gran Rapids, Nueva Creación, 1967, 1149. La fecha imprecisa de esta afirmación de Calvino se debe a que, como estuvo corrigiendo y aumentando permanentemente la Institutio, no sería posible datar estar afirmación más que con un cotejo exhaustivo de las ediciones que se sucedieron. Pero es evidente que, en algún momento, Calvino vio la conveniencia de disponer de un texto breve y claro, familiar, como él mismo dice. La descripción que hace del examen a que serían sometidos los niños responde a la perfección a lo que aparece en el Catéchisme, en el apéndice sobre la forma en que han de ser examinados los niños antes de ser admitidos a la Cena, como aparecerá más adelante.
} 
truire les enfans en la Chrestienté, faict en maniere de dialogue, ou le Ministre interrogue et l'Enfant respond. Par Jehan Calvin, A Geneve, de l'Imprimerie de Jehan Crespin, M. D. LII. (La variación en el título de ambas se puede deber a la modernización aludida). Este Catéchisme constituye un nuevo resumen de la obra magna, Institutio, o, si se prefiere, una síntesis más breve aún de la condensación que había llevado a cabo (Instruction et confession de foy, en francés, o Catechismus, sive christianae religionis institutio, en latín); aborda las mismas cuestiones que trató en las dos obras precedentes, aunque no se ajusta al mismo plan con exactitud; las variaciones más destacadas son las de reducir la cantidad de materia expuesta, la razones en que se apoya, o, sobre todo, disponerla en forma de diálogo ${ }^{16}$. Alguna edición no determinada de esta obra será el punto de referencia de las dos versiones castellanas estudiadas, aunque, como aparecerá más adelante, las variaciones que se aprecian entre las ediciones francesas consultadas de 1545 y 1552 da como resultado que también aparezcan variantes entre las versiones castellanas de 1550 y 1559 . La castellana de 1550 es reflejo más fiel de la precedente francesa de 1545; y la castellana de 1559 sigue los pasos de la de 1552 francesa, aunque con mucha libertad.

Con la ciudad de Ginebra ingobernable, pidieron a Calvino que dejara su retiro de Estrasburgo y regresara a hacerse cargo de los aspectos religiosos y civiles de la población. El regreso (septiembre de 1541) supuso la inauguración de la que se ha llamado ciudad teocrática, modelo de religiosidad ambiental, con férreas disposiciones y control absoluto de todas las actua-

\footnotetext{
16 Acaso esta duplicidad de catecismos, a la que hay que añadir la doble publicación de los mismos en latín y francés, hace que la referencia a la publicación de los mismos, así como sus títulos, resulte extraordinariamente confusa. E. MANGÉnOT, Catéchisme, en A. VACANT y otros (eds.), Dictionnaire de Theologie Catolique, II, $2^{\text {eme }}$ partie, 1090, dice: «Calvin, de son coté, publia deux catéchismes en français, l'un en 1537, l'autre en 1542; ils furent tous deux traduits en latin, 1538, 1545. L'un d'eux a été traduit en grec par Henri Etienne...». J. CoLOMB, Manual de catequética. Al servicio del evangelio, Barcelona, Herder, 1971,63, señala una fecha imposible: «En 1521, Calvino compone su "Catecismo de la Iglesia de Ginebra, es decir, formulario para instruir a los niños en la cristiandad, hecho a manera de diálogo, en que el ministro pregunta y el niño responde". Estas catequesis no eran muy diferentes respecto al método o programa de las catequesis existentes; se explica el símbolo de la fe, el padrenuestro, el bautismo y la cena. Pero quiere ser menos intelectual, presenta una palabra de Dios a la que hay que responder; prepara a la cena, que es como la respuesta a la palabra de Dios que se nos ha dirigido en el bautismo. Es, pues, una especie de catequesis de catecumenado entre el bautismo y la cena». Finalmente, L. CsonkA, Historia de la catequesis, en G. DHU, L. CsonKA, G.C. NeGRI, Educar, 3, Metodología de la catequesis, Salamanca, Sígueme, 1966, 140, propone una fecha no exacta: «Otros reformadores imitaron en seguida el ejemplo de Lutero, difundiendo sus propias doctrinas en fórmulas populares. El catecismo de Martín Buzer, de la secta de Zwinglio, en 1543. Y el de Calvino en 1535, son buenos ejemplos».
} 
ciones, públicas y privadas. Ese mismo año de 1541 publicó ya en Ginebra la edición francesa de la obra magna: Institution de la religion chrestienne en laquelle est comprissé une somme de piété et quasi toute ce qui est necessaire a cognoistre en la doctrine du salut. Se trataba no sólo de una traducción, sino además de una revisión de la obra latina de unos años antes, pues de los seis capítulos había pasado a diez y siete. A lo largo de su vida continuó retocando su obra capital.

Los refugiados españoles en Ginebra eran conocedores de los escritos de Calvino, y, especialmente interesados por el Catéchisme, por ser la obra más breve y sencilla, hubo dos personas (o tres si se tiene en cuenta la edición ya anotada de 1556), un desconocido traductor y Juan Pérez de Pineda, que emprendieron la labor de poner en castellano el texto de Calvino, con la finalidad de que pudiera ser difundido por España, y, de esta forma, dar a conocer sus ideas y conseguir nuevos adeptos.

\section{COMPARACIÓN ENTRE LAS DOS VERSIONES CASTELLANAS ESTUDIADAS}

No hay forma de evitar que ambas versiones se parezcan, puesto que se basan en la misma obra traducida al castellano. Pero los parecidos no pueden ocultar las diferencias.

Versión de 1550

-Titulo: Catechismo. A saber es formulario para instruir los mochachos en la Christiandad: Hecho a manera de Diálogo, donde el Ministro de la Yglesia pregunta, y el mochacho responde. Transladado de Frances en Español. Eph. I. El fundamiento de la Yglesia es la doctrina de los Prophetas y Apóstoles. 1550.

-Carta nuncupatoria.

-Carta del autor al lector.

-Nota metodológica.

"Fin del Catechismo"

Fe de erratas.

\section{Versión de 1559}

-Título: Catecismo que significa forma de instrucion: que contiene los principios de la religion de Dios, vtil y necessario para todo fiel Christiano. Compuesta en manera de dialogo donde pregunta el maestro, y responde el discipulo. Sal. CXIX. La declaracion de tus palabras alumbra. Y da cumplimiento a los pequennos. Nvevamente impresso. Año de 1559.

-No tiene carta nuncupatoria.

-Prólogo retocado, que incluye, disimula$\mathrm{da}$, la carta original.

-Carece de nota metodológica.

-Propone los formularios al principio. (En el texto, los repite: credo apostólico, mandamientos y padrenuestro).

-"Fin de la doctrina Christiana"

-Dispone de un índice, e incluye una serie de apéndices.

-Carece de fe de erratas. 
Aunque no sea más que por la simple comparación, es apreciable que las dos versiones son bien diversas. Dicho de otra forma, la versión de 1550 resulta, en la práctica, casi una versión literal de la obra original, el Catéchisme, de Calvino; mientras que la versión de 1559, permaneciendo fiel en la sustancia de la obra, en la parte central de la misma, no es versión tan literal, y desde luego se permite otra serie de cambios y licencias que no aparecían en la anterior.

La razón de las diferencias en los apéndices hay que buscarla en las ediciones francesas que he podido consultar, que resultan, por sus fechas, intercaladas con las ediciones castellanas estudiadas.

$1^{a}$. La edición francesa de 1545 sí tiene la «Carta al lector», pero carece de toda clase de apéndices al final.

$2^{a}$. La edición castellana de 1550 incluye la «Carta del autor al lector», pero va precedida de la carta nuncupatoria de la que carecía la edición francesa; tampoco incluye apéndice ninguno.

$3^{\mathrm{a}}$. La edición francesa de 1552, ofrece la «Carta al lector»; pero al final añade una serie de apéndices, que enumero: «Oraison pour dire au matin, en se levant» (p. 116-117); «Oraison pour dire devant qu'estudier la leçon à l'eschole» (p. 118-119)); «Oraison pour dire davant le repas» (p. 120); «Action de graces apres le repas» (p. 121); «Oraison pour dire davant que dormir» (p. 121-122); «La maniere d'interroguer les enfants qu'ou vant recevoir à la Cene de notre Seigneur Iesu Christ» (p. 123-127).

$4^{a}$. La edición castellana de 1159 ofrece una «Carta» modificada, que incorpora tácitamente las ideas de la «Carta al lector»; e incluye al final una serie de apéndices que sólo coinciden parcialmente con los que aparecían en la francesa de 1552. De hecho, los apéndices -tanto en la edición francesa como en la castellana- son formas prácticas de religiosidad tenidas en cuenta en la ciudad de Ginebra. Pensando acaso en esos destinatarios de habla española, la edición de 1559 es más amplia, aunque lo fundamental de ella sigue siendo el catecismo.

Es preciso añadir el estilo de traducción de cada uno de los que intervino, para marcar otra diferencia. La versión de 1550 es más literal, algo más forzada, y se desarrolla con poca fluidez. Las frases dependen demasiado del francés, como si el traductor desconocido, -que reconoce expresamente haber perdido contacto con el castellano por llevar una larga temporada en Ginebra («en esta ciudad»)- careciera de soltura para una traducción desenvuelta. Voy a poner algunos ejemplos del carácter de traducción forzada que aparecen en variadas ocasiones. Uno es el que consta en el mismo título; dice: «Catechismo, a saber es formulario...». Pues bien, en la edición de Ginebra, 1552, el título francés comienza: «Catéchisme, c'est a dire, le for- 
mulaire...». El «c'est a dire» ha pasado al castellano forzado de «a saber es» 17 , en lugar del más natural «es a saber», o, como propone la versión de 1559 «que significa».

Otro ejemplo, de los muchos que se podrían proponer, es la pregunta $14^{a}$. Ésta, en francés es: «Ministre : Le fondement donc d'avoir vraie fiance en Dieu, c'est de le connaître en Jésus-Christ.- Enfant: Voire». En la versión de 1550 aparece como: «Ministro: El fundamiento pues de tener verdadera confiança en Dios, es de conoscerle en Iesu Christo.- Mochacho: Assí es verdad». La versión de 1559, la presenta de la siguiente forma: «Maestro: Luego el fundamento y principio para poner en Dios toda nuestra confiança es conocerle en Iesu Christo.- Discípulo: Es assi cierto». La muestra ofrecida denota que la versión de 1550 es más encorsetada y rígida, en tanto que la posterior de 1559 se mueve con mayor soltura y naturalidad.

Hay otra muestra que no puedo omitir, cuando habla de la condenación y muerte de Jesús, donde la versión de 1550 dice: «... y en este medio fue solemnemente condempnado por la sentencia del mesmo juez, para denotar que él es nuestra verdadera capción, pues recibiendo la condemnación nos eximió della» (p. 24). La edición francesa de 1545 propone «pleige» 18 para lo que está traducido como «capción» en la de 1550; pero la edición castellana de 1559 dice con mucha más claridad: «... para denotar que es verdaderamente nuestro fiador...».

En el mismo contexto de la condena de Jesús, la expresión original francesa que se refiere a Pilato aparece así: «par le temoignage du juge»; es vertida en la edición de 1550 como «por el testigo del juez», con una falta total de soltura; mientras que la edición de 1559, más pulida, la muestra como «dio el juez testimonio...», interpretando adecuadamente el sustantivo original ${ }^{19}$.

17 En las páginas 44 y 87 de esta misma versión aparece dos veces más la expresión forzada «a saber es», como muestra de la deficiencia de traducción: «Assí es ello. Y por esso la Doctrina del Euangelio se comprehende en dos palabras (a saber es) Fe y Penitencia» (p. 44); «Como las palabras que Iesu Christo vsó nos le muestran, a saber es, que nuestros pecados son deudas...» (p. 87).

18 «... et cependant est condamné solennellement par la sentence d'icelui même pour dénoter qu'il est vraiment notre pleige». «Pleige» es término arcaico, que tiene como equivalente jurídico la palabra «caución», como garantía de un compromiso establecido. La versión de 1550 como «capción» es literal, mientras que la de 1559 como «fiador» está más próxima al sentido de garantía o prenda, que tendría en el castellano actual.

19 Este mismo fallo, forzado, se aprecia en otros lugares de la edición de 1550: «...Y assí como él mueve su gracia y amor sobre sus seruidores bendiziendo a sus hijos, assí es vn testigo de su venganza sobre los iniquos» (p. 50, sobre el castigo por mil generaciones); «Que el 
Todavía hay otra diferencia más entre las ediciones castellanas, poco apreciable, pero real: la edición de 1559, en los ladillos, no siempre reproduce con exactitud las referencias y citas bíblicas que aparecían en la versión anterior; hay una especie de reajuste en algunas ocasiones, pocas, en verdad. A veces añade alguna referencia, y otras desaparece alguna del original. No sucede con frecuencia, pero es preciso anotarlo.

\section{LA CARTA DEL AUTOR AL LECTOR}

Paso, por tanto, al examen de lo que las versiones castellanas presentan. Además de la carta nuncupatoria, que aparece únicamente en la edición de 1550 , las dos versiones tienen una carta al lector. Pero también en esto existe una diferencia: la versión de 1550 la titula, en singular «Epístola del avctor al Lector», mientras que la de 1559 dice, en plural, «A todos los amadores del Señor Iesu Christo, y que biuen en la esperança de su venida, Salud».

El original francés daba el título más escueto de «Épitre au lecteur», carta que, evidentemente, procedía del autor, Calvino. La versión de 1550 hace una traducción exacta y completa de la carta, y señala que procede del autor, pero no del traductor (de éste es la carta nuncupatoria en que solicitaba ayuda para costear la edición). Ocupa parte de las p. 7 y 8, con una extensión de una página aproximadamente. Ahora bien, la versión de 1559 ofrece una larga carta preliminar, con la dedicatoria reproducida antes. Esta carta ocupa las páginas 3 a 14, es decir, once páginas y media; es evidente que algo ha cambiado. En ella el traductor, Juan Pérez de Pineda, se explaya a su aire sobre sus convencimientos calvinistas que desea transmitir a sus lectores. Pero, examinada con detalle, la carta tiene su cierto misterio, puesto que, sin ninguna indicación que lo hiciera sospechar, y sin señalar su procedencia, asume e incorpora casi todo de lo que aparecía en la carta de presentación de Calvino, pero lo hace tan disimuladamente que, de no tener a la vista las dos versiones, esta amalgama hubiera pasado desapercibida. Ofrezco a dos columnas ambas secciones, destacando en la segunda columna con cursiva aquello que es igual en las dos, es decir, el texto íntegro de la carta al lector, que redactara Calvino:

pueblo se ajunte para ser instruydo en la palabra de Dios, para hacer las rogarías comunes, y dar testigo de su Fe y religión» (p. 57, en lugar de dar testimonio; aparece aquí otro punto forzado de «rogarías» en lugar de «oraciones»); «¿Qué cosa es Sacramento? - Un testigo exterior de la gracia de Dios...» (p. 95); «¿Con qué condición, pues, deuemos baptizar los niños? En señal y testigo que son herederos de la bendición de Dios...» (p. 105). 
Versión de 1550

Cosa singularmente encomendada

ha sido en laYglesia de instruyr los mochachos pequeños en la doctrina Christiana.

Para lo qual antiguamente no solo tenian las Escuelas

y mandauan a cada vno que adoctrinasse bien su familia,

pero el orden publico de los templos era de examinar los mochachos pequeños sobre todos los puntos que deuen ser comunes entre los Christianos, y para en ello proceder por orden vsauan de un formulario que llamaban Catecismo.

\section{Despues}

el Diablo dissipando

la Yglesia, y haziendo en la mayor parte del mundo la espantosa ruyna que aun se veen las señales, destruyo esta sancta policia, dexando solamente algunas reliquias

que engendran

supersticion sin edificacion alguna.

Esto es la Confirmacion, que llaman, en la qual no ay sino un Juego de Ximios sin ningún fundamento.
Versión de 1559

... Esta forma de doctrina no es cosa nueua, como falsamente piensan los que tienen perdido el gusto para las cosas del cielo. Doctrina es, que enseñaron los Prophetas y los Apóstoles de Iesu Christo maestro de vnos y otros: y que desde el principio se enseño en la primitiua Yglesia. Instituyr los pequeños en ella fue siempre muy vsado, y estimado entre los fieles y para que fuessen bien instituydos vuo antiguamente deputadas escuelas donde se enseñaua. $\mathrm{Y}$ con esto se mandaua estrechamente, que por ella doctrinasse cada vno su familia. Auia tambien por los templos orden publica de examinar los mochachos en los articulos de la religion, que eran comunes, en que consentian todos los Christianos. Y para proceder en esto con fructo, vsauan de vn sumario de doctrina llamado Catechismo (que quiere tanto dezir como instrucion o enseñanza que se haze por palabra y biua voz), en que estaua recapitulado todo lo que concierne a la Christiandad. Despues andando el tiempo, disipo el demonio la Yglesia, y hizo en ella vn muy horrible estrago, del qual aun en la mayor parte del mundo se veen todavia las señales: y destruyo con su rabia esta santa policia, tanto que no dexo sino algunas hezes y escorias, que son de tal condicion y naturaleza que no pueden engendrar sino supersticion $y$ vanidad, sin ninguna edificacion de Dios. Lo que se introduxo en lugar de aquel diuino enseñamiento es lo que agora llaman Confirmacion: con que los Obispos confirman a los mochachos quando son de tierna edad: cosa sin ningun verdadero fundamento, $\mathrm{y}$ sin fructo Christiano. Vntar con azeyte al mochacho la frente, $y$ atalle vna venda, y dalle vn bofetoncillo, para que (como ellos dizen) se acuerde de lo que con él se hizo, vease que similitud tiene esto con enseñar puramente con biua voz la doctrina que mando Dios que todos Chicos y grandes supiessen, para ser por ella confirmados en la fe de lo que confiessan, y que la tuuiessen por regla con que regirse para agradarle en 
Y así

lo que agora ponemos delante es el vso que

de toda antiguedad los Christianos han guardado,

el qual nunca han dexado hasta que la Yglesia ha sido totalmente corrompida. todas cosas. Lo vno tiene ser verdadero y fundamento de Dios, pues es mandado por el, y lo que sucedio, carece de lo vno y de lo otro. Esto, pues que el mando es lo que aqui proponemos a todo fiel: conviene a saber, el vso de enseñar y aprender la doctrina de la verdad, que fue familiarissimo antiguamente entre los Christianos. Todo el tiempo que vuo pastores de nombre y de obra, enseñados y embiados de Dios a apacentar con su pura palabra y a gouernar la Yglesia, duro este sancto vso: pero faltando ellos, y viniendo ella a estar totalmente corrompida por la ingratitud y menosprecio de los beneficios diuinos, se dexo y puso en olvido...

Sin decirlo, sin siquiera mencionar que la incorpora, en el fragmento de la carta o presentación de la segunda edición examinada aparece completo el texto de la primera. Se aprecia algo que ya he apuntado: la mejora de la calidad y estilo de una versión a otra. También aparecen algunos criterios que añade por su cuenta Juan Pérez de Pineda. Quiero fijarme en primer lugar en el relativamente extenso párrafo que dedica a la confirmación, en que asegura que lo fundamental es confirmar la fe, y no la ceremonia de la unción (como si se tratase de dos cosas opuestas entre sí, o la celebración católica no pretendiera también la reafirmación de la fe de quien recibe el sacramento). Añade, además, que «lo vno tiene ser verdadero y fundamento de Dios», es decir, la forma práctica asumida por la Reforma, «pues es mandado por el», $y$, por el contrario «lo que sucedio», con el transcurrir de los años y de las prácticas eclesiales «carece de lo vno (ser verdadero) y de lo otro (fundamento)».

Eran tiempos de polémica y no de tender la mano a otros. Y se incurrió en la simplificación de que todo lo que hacían unos era bueno (sin matizaciones ni adaptación), mientras que todo lo que hacían los otros eran nefasto (igualmente sin matices ni excepciones). $Y$ es natural que hoy lo encontremos así. Cosa bien diversa será que en la actualidad se pueda mantener una simplificación tan elemental, que por sí misma reclama ser mejor sopesada.

La otra afirmación en que quiero fijarme es la expresión que aparece en la primera versión, también a propósito de la confirmación, de la que afirma que es «un Juego de Ximios». La expresión francesa, original, dice así: «C'est la confirmation, qu'on appelle, où il n'y a que singerie sans aucun 
fondement». La palabra singerie quiere decir, en efecto, algo que realizan los simios, (de singe, simio, mono); también tiene el sentido de algo sin valor, carente de fundamento, y podría traducirse por «una tontería, o una monada». Sin embargo, es preciso ir un poco más lejos, porque a la expresión simiesca se le atribuye una connotación diabólica, malvada. No es posible olvidar que en la frase inmediatamente anterior, Calvino ha hablado de la intervención del diablo, que ha corrompido la legítima actuación de la iglesia: «Depuis le diable, en dissipant l'Eglise et faisant l'horrible ruine dont on voit encore les enseignes en la plupart du monde, a détruit cette sainte police et n'a laissé que je ne sais quelles reliques, qui ne peuvent sinon engendrer superstition, sans aucunement édifier». En consecuencia, la frase tiene un sentido peyorativo, y singerie adquiere el sentido de hacer «diabluras o maldades». La versión de 1550 , tan apegada al francés, no captó totalmente el sentido, y la frase quedó con un cierto tono ofensivo y burlesco, que parecía ridiculizar la acción litúrgica de la confirmación católica, cuando en realidad tenía un sentido de acusación. Era el estilo de la época, y no podemos pretender en la carta al lector un estilo dialogante, propio de nuestros días.

La versión de 1550, más rígida, por su dependencia del francés, es, por otra parte, más fiel, pues nada quita ni pone. Al contrario, la versión de 1559 , que incorpora de tapadillo todo el contenido de la carta de presentación, la envuelve de tal manera en otros pensamientos y motivos, que, al final, no se sabe lo que tiene mayor importancia; su fidelidad es menor, dada su mayor libertad de expresión y de actuación.

\section{LA NOTA METODOLÓGICA}

Es uno de los rasgos que diferencia ambas versiones, aunque advertí que, tácitamente, está articulando la versión de 1559, aunque no figure en ella de forma expresa.

De entrada es imprescindible hacer una aclaración: tal nota no figura en el texto francés original. Es posible que Calvino o cualquiera de los ministros que enseñaban en Ginebra o en otras ciudades de mayoría calvinista lo indicaran de palabra, o lo tuvieran tan presente que no fuera necesario ponerlo escrito en el catecismo. El traductor desconocido, con otro criterio, la redactó de esta forma:

«La manera desta instruction es que los Domingos a medio día se ayunta el pueblo en los Templos, donde los Ministros despues de auer preguntado a los mochachos sobre los artículos contenidos en este libro, les declaran particularmente, para que el pueblo sea mejor instruydo y edificado, y esto por el 
tiempo de vna hora. Lo que en cada Domingo se declara, está notado en el margen».

Si comenzamos a examinarla por el final, en efecto tanto el texto primitivo francés como las dos versiones castellanas estudiadas presentan en ladillos la distribución de la materia, para que cada domingo se examine una parte del total, dosificada, y que tiene aproximadamente la misma extensión. Por ello, las dos versiones castellanas son fieles a la disposición y distribución de materia; pero la originalidad de la versión de 1550 proporciona, además otra serie de datos.

En primer lugar, declara que la catequesis tiene lugar los domingos y no otro día cualquiera. Es una forma de guardar el debido respeto a Dios y santificar el día principal para los cristianos. Añado, por mi parte, que son muchísimas las disposiciones católicas que ordenaban lo mismo para sus fieles.

En segundo lugar, la agrupación para la catequesis tiene lugar a mediodía, con precisión. Es la característica personal de Calvino de no dejar las cosas desorganizadas, sino, bien al contrario, precisar y reglamentar. La misma disposición, reglamentada, aparece en numerosas ordenanzas católicas, en que los sínodos locales, o los obispos directamente estipulan el día y la hora previstas para la catequesis.

En tercer lugar, señala que se reúnen en el templo. Tampoco consiste novedad alguna, sino concreción. Era el local disponible por la comunidad cristiana, y al que acudían para aquello que tenía que ver con su vida cristiana. Y la catequesis tenía que ver con esto.

En cuarto lugar, la disponibilidad de tiempo era de una hora para la doble tarea que señalo a continuación. Tampoco en esto había grandes novedades respecto a la enseñanza católica. Ni tampoco hay que pretenderlas. Hijos de su tiempo, los miembros de las diversas confesiones en que se fragmentó el grupo de cristianos, unidos hasta entonces, acuden a los procedimientos de su época, los que les parecen más normales o más válidos, sin buscan innovaciones propias de otro tiempo.

En quinto lugar, indica la doble tarea que tienen los ministros. La primera de ellas es preguntar y comprobar si los niños saben bien las respuestas que tienen escritas en el catecismo. No dice cuándo o dónde tienen que aprenderlas, pero es evidente: la carta al lector señalaba como práctica tradicional que se enseñase en las casas y que cada uno se responsabilizara del aprendizaje de los miembros de su familia. Por tanto, el ministro comprobaba si los niños sabían lo establecido para ese domingo. Flota en el ambiente una cuestión de tipo pedagógico: la comprobación que hacían los ministros apuntaba a si sabían repetir las respuestas, o más bien a si sabían 
comprenderlas. Parece más bien que hay que pensar en la primera de las dos posibilidades, por lo que sigue a continuación. Con esto quiero decir que el aprendizaje llevado a cabo entre los calvinistas no era de mejor ni peor calidad que el que se practicaba entre católicos, para los cuales el primer paso consistía también en saber repetir lo que decía el catecismo. Esto lleva de la mano a la segunda tarea de los ministros: que les declaren particularmente, es decir, que les expliquen, para que estén mejor preparados. No era suficiente con repetir, y había que dar el paso siguiente, hasta comprender tras una explicación. Tampoco hay en esto diferencia notable con el pensamiento católico, que apuntaba en la misma dirección. Pero la importancia de esta nota metodológica estriba en hacernos llegar estos criterios, y no simplemente que los demos por supuestos. El hecho de que figure únicamente en la versión de 1550 podría deberse a la iniciativa privada del desconocido traductor, quien rememoraba su pasado católico en España, antes de su huida a Ginebra. También podría deberse a la actuación práctica que él veía, y que pone por escrito para que otros la tengan presente.

Con respecto a la distribución de la materia, hay varias cosas que comentar. La primera es que, por el hecho de encontrársela ya establecida, el ministro no disponía de libertad para extenderse, ampliar, fundir, o acomodar la materia. La distribución así reglada, tiene algunos fallos, y es la segunda observación pertinente. He indicado que la cantidad de materia para cada sesión de catequesis venía a ser aproximadamente la misma para cada domingo. Sin embargo, hay fallos desde el punto de vista de la pedagogía, porque en más de una ocasión se marca la división de forma arbitraria, dejando preguntas de un mismo asunto en domingos diferentes. Es, como ejemplo, lo que sucede en el domingo 44: deja para él la última pregunta, aislada, relativa a la oración, y comienza con la cuarta parte del catecismo, la de la palabra y los sacramentos; lo lógico hubiera sido incluir esta pregunta, la 295, en la materia del domingo anterior, y comenzar un nuevo tema. La división de la materia, aproximada, artificial y poco pedagógica tendría que haber seguido otros criterios, pero no fue así.

La tercera observación sobre la distribución de la materia resulta todavía más llamativa; no es preciso echar mano de criterios pedagógicos que hoy nos pueden parecen normales, sino de una reflexión elemental y directa de cualquiera que se pusiera a ello; además, la misma práctica tenía que demostrar lo improcedente de esa distribución. La materia está repartida en el catecismo para 55 domingos. Y los domingos del año son 52. No se corresponden. Bien quedaba materia para tres domingos más, bien no se veía y se iniciaba el año de nuevo no en la misma fecha, sino con casi un mes de desfase. No hubiera resultado muy difícil caer en la cuenta de algo que el correr 
de las semanas demostraba. Además, no hay nada previsto, como tema especial para, por ejemplo, el domingo de Pascua; que ese día coincidiera la materia o no con la conmemoración de la resurrección del Señor, y que hubiera que hablar de la cuarta petición del padrenuestro, era un asunto intrascendente.

Finalizo este apartado con una pregunta que queda en el aire. La doble tarea de los ministros de comprobar si los niños sabían repetir las respuestas, para proceder luego a su explicación obliga a preguntarse: ¿Con qué medios preparaban los ministros sus explicaciones? La nota metodológica no lo dice, acaso porque no está dirigida a los ministros. Es previsible que, acorde con la graduación de medios preparada y redactada por Calvino, al Catéchisme, le pudiera corresponder como instrumento de explicación la Instruction et confession de foy, de nivel y contenido superior; o también la misma Institution de la religión chrétienne, obra máxima. El instrumento ínfimo, destinado a la formación de los niños, reclama, por lógica, los otros dos superiores para su explicación.

\section{SIGUIENDO CON LA PEDAGOGÍA}

Todos los catecismos, de cualquier procedencia que sea, en que pregunta el educador y responde el educando tienen como elemento común que se pone en labios del último lo que debería saber, pero todavía desconoce. Se le ofrece la respuesta; y se tiene que limitar -en lo que da de sí el texto- a repetirlo. Después, en el mejor de los casos, vendrá la explicación que se le pueda suministrar a lo que ha repetido sin entender.

Como se trata de respuestas religiosas, en temas que en más de una ocasión eran tema de debate, o compendiaban un misterio, o transmitían una enseñanza precisa, lo corriente es que las respuestas sean muy aquilatadas; no vale cualquier respuesta, ni es admitida la improvisación. Más aún, si el educando tiende a dar su propia respuesta, o acomodar lo leído a lo que capta su mente, es fácil que se equivoque y no exprese la fe exacta de una determinada confesión. Ante el riesgo de desviaciones, errores o sinsentidos, lo corriente es exigir la recitación de memoria de la respuesta, que no contiene error. Luego vendrá la explicación o adaptación para que capte con su mente de niño, adolescente o adulto lo que se le ha presentado.

Esto mismo sucede en los catecismos examinados. Cada uno de ellos, con su diverso estilo de traducción, son fieles a las respuestas originales. Y dichas respuestas no siempre podían ser entendidas sin explicación, dados los matices que encierran. La mejor de las prácticas catequéticas y pedagó- 
gicas es precisamente la contraria: que sea el educando quien pregunte, que lo haga sobre lo que no entiende o capta; y que el educador responda adecuada y proporcionalmente a su pregunta con una respuesta veraz, aunque más adelante sea preciso volver sobre ella. Hay un buen puñado de catecismos que optan por este criterio. Todavía es mejor procedimiento que en un verdadero diálogo espontáneo, no tipificado, ni escrito, vayan saliendo las cuestiones, las dudas, las explicaciones, las reiteraciones,... Y, sólo después, cuando ya ha sido visto, explicado y aclarado, el texto escrito sirva para recordar y fijar lo que se sabe.

Esto no sucede en la inmensa mayoría de los catecismos. Y la mayor parte de los responsables de la educación de los cristianos -en una u otra confesión- se han limitado muchas veces a exigir un aprendizaje de pura memoria, poco convincente y poco rentable. Es el riesgo que existía también con este catecismo, en cualquiera de sus ediciones.

En el catecismo de Calvino, en particular, las intervenciones del Ministro en ocasiones no son preguntas, sino afirmaciones doctrinales, propuestas de asertos de fe, síntesis de datos; ante ellos, el niño se limita a repetir una y otra vez la respuesta: «Assí es ello», o «es así». En estos casos, nada raros, es un diálogo, en que uno afirma y el otro se limita a aceptar y asentir. El diálogo casi ha derivado en monólogo.

Tampoco son raras las intervenciones en que la respuesta es un monosílabo (si, no), que conduce a la pregunta siguiente. Es algo normal para el desarrollo escrito de un texto de catecismo, aunque la realidad viva del diálogo discurre por otras vías. Otras veces, es la pregunta la que está formada por una sola palabra (¿Cuál?, ¿cuántos?) con la intención de proseguir en la pregunta siguiente lo enunciado en la anterior. Son las limitaciones de las preguntas o respuestas de una sola palabra.

En ocasiones, la respuesta es notablemente complicada para que el niño la entienda; la explicación posterior tendría que afinar y aquilatar las cosas. En algunas ocasiones, las mejores explicaciones topan con una dificultad real, al hablar de los misterios. Es el caso de las preguntas 19 y 20 sobre la Trinidad; las mejores respuestas de los catecismos, las palabras más ajustadas y cercanas a la mentalidad del destinatario se quedaban siempre cortas. Por eso, en las dos preguntas señaladas, la primera tiende a hacer una descripción ajustada de lo que percibimos del misterio; y la segunda es una de las propuestas afirmativas -que no pregunta- que hace el ministro: «Tú quieres dezir que no ay inconueniente alguno que en vna mesma Diuinidad comprehendamos distintamente estas tres personas y que Dios no por esso es diuidido». El niño responde: «Así es ello», y asiente a lo que se le dice. 


\section{ESTRUCTURA DEL CATECISMO}

Se trata de un estructura relativamente simple. Hay seis preguntas iniciales sobre el fin del hombre y la honra de Dios. Con ello se llega a la séptima pregunta que es la que propone la articulación del conjunto: «¿Cómo le deuemos bien honrar? -Teniendo toda nuestra confianza en el, siruiendole obedeciendo a su voluntad, llamándole en todas nuestras necessidades, buscando en el nuestra salud. Y confessando de coraçón y de boca que dél solo procede todo bien» 20 . Hay, por consiguiente, cuatro partes, pero la primera sobre los artículos de la fe o el símbolo, y la última sobre la palabra y los sacramentos, están a su vez subdivididas. No hay que ver como subdivisión el ir explicando los mandamientos uno a uno, así como las varias peticiones del padrenuestro, pues en estos casos se limita a seguir un procedimiento rectilíneo al exponer cada uno de los mandamientos y peticiones.

El esquema es el siguiente:

* Fin del hombre (preg. 1-7).

* Parte I: de los artículos de la fe.

- Acerca de la fe; credo apostólico, división del credo (preg. 8-16). La pregunta 16 contiene el texto del credo apostólico ${ }^{21}$.

- Trinidad (preg. 19-20).

- Padre: nombre, poderoso, providente, creador, controlador (preg. 21-29).

- Jesús: nombre, triple función, hijo único, encarnación, señorío, condena y muerte, consecuencias, resurrección, ascensión, gloria, vuelta y juicio (preg. 30-87).

- Espíritu Santo (preg. 88-91).

- Iglesia: nombre, santa, católica, comunión de los santos, remisión de pecados, resurrección, vida eterna, fe, obras, evangelio, justificación, penitencia (preg. 92-128).

* Parte II: Mandamientos: ley, dos tablas, voluntad y honra de Dios, imágenes, juramento, descanso, domingo, padres, homicidio y odio, fornica-

20 Lo cierto es que tal como consta en la versión de 1550 , el empleo de seis verbos en gerundio (teniendo, sirviendo, obedeciendo, llamándole, buscando y confessando) despista, sin saber con exactitud cómo articula la respuesta. El recurso al mismo texto en otras ediciones despeja las dudas posibles. La redacción de la versión de 1559 es algo más clara: «Que pongamos en el toda nuestra confiança. Que siempre le sirvamos obedeciendo a su voluntad. Que le invoquemos en todas nuestras necessidades, buscando en él la salud y todos los bienes que se pueden dessear; y que a él solo conozcamos de coraçon y de boca por autor de todos los bienes».

21 La Confesión de Fe llamada de La Rochelle, que data de 1559, expresión común de todas las confesiones y grupos franceses derivados del calvinismo, reconoce en su artículo $5^{\circ}$ como válidos tres credos: el credo apostólico, el credo de Nicea y el atanasiano. 
ción, cuerpo, hurto, mentira y malpensar, codicia, resumen de los mandamientos, función de la ley, ayuda de los hombres, ángeles y santos (preg. 129239).

* Parte III: Oración: de palabra y corazón, sólo de palabra, confianza, por Jesús, oraciones no inventadas, padre nuestro y sus peticiones (preg. 240-295). La pregunta 256 es el texto del padrenuestro22.

* Parte IV: La palabra y los sacramentos.

- La palabra: escritura, palabra divina, lectura, predicación, los pastores en la iglesia (preg. 296-308).

- Sacramentos: definición, eficacia, número, diferencia, bautismo, regeneración, bautismo de niños; cena, significado, comunión, sin oblación, dos especies, condiciones para recibirla, necesidad, ministros, discernimiento, orden eclesial (preg. 309-373).

La proporción de cada una de las partes en el conjunto del libro ofrece una idea de la importancia que le atribuye, y cómo están desarrolladas en mayor o menor medida. El fin del hombre representa el 1,87\% del total; la parte primera, sobre los artículos de la fe equivale a un $32,43 \%$, la más desarrollada; lo correspondiente a los mandamientos le sigue en orden de importancia con un $30,02 \%$; la parte que se refiere a la oración sólo llega a un $15,01 \%$; y por último la palabra de Dios y los sacramentos representan el 20,91\%.

Ya he indicado antes que el extracto de la Institutio, con sus dos títulos según las versiones (Instruction et confession de foy, o en latín Catechismus seu christianae religionis institutio, ambas con 33 capítulos) no mantiene con exactitud el mismo esquema que el Cathécisme breve, aunque sí aparecen en las dos obras las cuestiones fundamentales. El Catechismus dedica una parte notable (7 capítulos) a la religión, al hombre pecador, la libertad, el pecado y la salvación; a continuación habla de la ley de Dios (capítulos 812, donde explica los mandamientos); sigue un extenso tratado sobre temas claves para Calvino: la elección y predestinación, la fe, la santificación por la fe, la obediencia, y las obras (capítulos 13-19); después viene el símbolo de la fe, con su explicación artículo por artículo, junto con el tema de la esperanza (capítulos 20-21); aparece después el tema de la oración, con una explanación del padrenuestro (capítulos 22-25); luego se centra en los sacramentos, donde precisa lo que son y lo que no son, y los dos sacramentos

\footnotetext{
22 El texto bíblico sigue la redacción de Lc. 11, y añade el tropo «Porque a ti pertenece el Reyno, el poderío y la gloria por todos los siglos de los siglos», que, como es sabido, no procede de la biblia, sino que forma parte de la Didache, VII, 2: «Porque tuyo es el poder y la gloria por los siglos».
} 
admitidos, bautismo y cena (capítulos 26-29), y los últimos capítulos (30-33) los dedica a los pastores de la iglesia, las tradiciones humanas, la excomunión y los magistrados. Es evidente que el orden y la estructura no es coincidente con la del catecismo breve.

La obra máxima (Institutio), al ser mucho más extensa, y abordar los temas con mayor profundidad -y con mucho más sentido polémico- se parece en su estructura todavía menos al catecismo breve. Aparecen los temas de la incapacidad del hombre pecador, y de la Escritura como garantía de la fe (libro I); el libre albedrío y la ley, donde constan los mandamientos (libro II); la manera de participar en la gracia y en la regeneración (libro III); la verdadera iglesia, frente a los abusos de la de Roma, y la práctica de los sacramentos (libro IV).

La diferencia en la extensión y en las proporciones varía entre ambos escritos, porque, como obras polémicas que son, se detienen con cierta frecuencia en demostrar que sus afirmaciones son verdades, y que son falsas las que llevan a cabo los católicos. El catecismo breve, al no entablar polémica, ofrece otra proporción. Sin embargo es posible espigar las cuestiones que están presentes en el catecismo con otro esquema y en otro orden: son convencimientos fundamentales para Calvino, y aparecen en momentos diferentes respecto de las dos obras (Institutio y Catechismus) sobre las que se basa el catecismo.

La articulación de la fe cristiana en cuatro partes no constituye novedad alguna, puesto que muchos catecismos contemporáneos así lo hacían. En cambio, el seguir un orden u otro es parte de las muchas variantes que se pueden combinar. Al fin y al cabo es un dato peculiar de cada autor organizar los saberes de la fe en un orden concreto, y sólo va a depender de los criterios con los que cada libro está concebido.

Las dos versiones castellanas examinadas conservan escrupulosamente la estructura y la división de la materia. No introducen ninguna afirmación que pudiera suponer alguna adaptación al público español, salvo en los preliminares, pero no en el texto del catecismo propiamente dicho; menos aún alguna pregunta nueva.

\section{EsTILO}

A diferencia de la Institutio, mucho más polémica y de tono más agresivo, incluso recurriendo al insulto y la descalificación, y de la Instruction et confession de foi, que resulta más serena en forma expositiva, el Catéchisme tiene un estilo mucho más sobrio y respetuoso, acaso por la mayor conci- 
sión; ésta es la tónica general que aparece en su lectura. Las versiones castellanas examinadas siguen esa misma tónica. La versión de 1550, más directamente apegada al texto original francés lo hace con mayor sobriedad; la versión de 1559 , un tanto más libre y elegante, se distancia un poco en cuanto a las expresiones, pero mantiene la misma línea de fondo.

Es preciso señalar que en un libro destinado a niños, para que aprendieran lo fundamental de la fe, tampoco tenía demasiado sentido recurrir a la descalificación o a la burla. Quizá hay que buscar ahí la razón de un estilo sobrio y, en general, respetuoso. Ya ha habido ocasión de comentar la frase que podría resultar más hiriente, en la carta al lector. La diferencia de connotación es, curiosamente, gradual, porque la edición francesa contiene un desprecio a propósito de la confirmación, entendida como singerie, diablura o maldad; la versión de 1550 lo modifica casi hacia lo burlesco, con «juego de simios», y la versión de 1559 elude la calificación, y deriva por mostrar la futilidad de la confirmación, haciendo una descripción, como si el rito externo fuera lo importante para los católicos, y careciera de fundamento el hecho de reafirmar la fe, dejando caer que esto sólo se daba en verdad en el calvinismo.

En el resto de las expresiones, especialmente en aquellas cuestiones en que existe discrepancia entre católicos y calvinistas, o entre éstos y otros grupos derivados de la Reforma, no hay calificativos que impliquen desprecio hacia los demás, o superioridad al exponer su pensamiento. Se puede, por tanto, afirmar que el catecismo tiene un estilo respetuoso, digno de ser tenido en cuenta. Es lógico, por otra parte, que, por ser expresión de sus convencimientos, dé a entender que lo que presenta es la doctrina cristiana legítima, pero esto no lleva a ridiculizar o ironizar sobre otras posturas.

\section{Principales Cuestiones TeOlógicas}

Como instrumentos para la formación cristiana de los niños, los catecismos contienen aquellos puntos que integran el pensamiento de la confesión correspondiente. Es, por tanto, natural que aquí aparezcan estas grandes afirmaciones que articulan el pensamiento calvinista.

1. La fe.- Es entendida en el sentido no sólo de conocimiento intelectual, sino actitud por la que el hombre deposita la confianza en Dios; así, en la pregunta $7^{\mathrm{a}}$, que establece la división del catecismo en cuatro partes, la primera de ellas, consiste en «tener nuestra confianza en él» (p. 10) ${ }^{23}$. Des-

${ }^{23}$ En las referencias de este apartado sobre las principales cuestiones teológicas, cito por la edición de 1550, y, si existe alguna variante digna de consideración, por la de 1559; cuando 
pués, cuando desarrolla esta primera parte del catecismo, en el encabezamiento de las páginas, emplea la antigua denominación de «artículos de la fe» 24 , para desglosar y explicar el credo apostólico, expresión y síntesis de la fe. Al concluir la exposición del credo, pregunta explícitamente qué es fe:

«Pues que tenemos el fundamiento sobre el qual la fe está cargada, bien podemos concluyr quál sea la verdadera Fe. -Es verdad, a saber, vn cierto y firme conocimiento del amor que Dios nos tiene, según quen su Euangelio lo muestra, declarando ser nuestro Padre y saluador, por el medio de Iesu Christo» (p. 39).

Esta concepción está presente a lo largo de todo el catecismo cada vez que alude a la fe como actitud básica del creyente.

2. Postración del hombre.- Mantiene una vinculación lógica con el apartado precedente, puesto que el hombre necesita apoyarse en Dios, dada la incapacidad de hacer nada por sí mismo. Es la concepción del hombre pecador, viciado radicalmente para cualquier obra buena, y más aún para hacer algo por su propia salvación. La raíz está dañada, y «todos somos pecadores» (p. 40), por lo que toda actuación humana está orientada hacia el mal: «no podemos dexar de peccar» (p. 41) (o la expresión de la versión de 1559: «ninguna cosa podemos sino pecar», p. 55). Por eso mismo, las obras que el hombre puede hacer, «aunque tengan por defuera buena apariencia... son naturalmente viciosas» (p. 102).

Como consecuencia de lo anterior, cuando habla de la intervención del Espíritu Santo al momento de la encarnación de Jesús, el Espíritu sana la corrupción, puesto que Jesús asume una naturaleza humana que está dañada:

«A causa que la simiente humana es della misma corrompida, conuenía que la virtud del Spiritu sancto entreuiniesse 25 en esta concepcion para preseruar a nuestro Señor de todo corrompimiento y henchirle de sanctidad» (p. 21).

Es la excepción a la norma universal. Resulta llamativa esta propuesta, en la que no aparece para nada la condición divina de Jesús; ésta queda a

es preciso, acudo a la edición francesa de 1545, o también a la de 1552, para sopesar la calidad de las versiones castellanas.

24 En los catecismos españoles, desde la época medieval, era tradicional el nombre de «artículos de la fe» para designar dos septenarios de afirmaciones, siete en torno a la divinidad, y otras siete en torno a la persona de Jesús. La expresión, acuñada, diferenciaba este formulario de la recitación del credo, aunque contuvieran los mismos contenidos de fe con expresiones diferentes. Calvino utiliza la expresión para referirse a las afirmaciones que aparecen en el credo, y no para los septenarios.

25 Equivalente a «interviniese». 
salvo, pero estaría contaminada al unirse con la condición humana, pecadora. Para equilibrar la situación, la intervención del Espíritu Santo resulta decisiva.

Pero, salvada la excepción de Cristo, la condición humana es corrompida. La cuestión sale una y otra vez; pero quiero fijarme en una pregunta, en una vieja reclamación humana hacia Dios, que tiene una expresión válida en el antiguo testamento:

« ¿No es contrario a la justicia de Dios, de castigar los vnos por los otros? -Si consideramos la calidad del linaje humano, esta question está determinada ${ }^{26}$. Porque naturalmente somos malditos, y no podemos quexarnos de Dios, si él nos dexare en nuestro propio ser natural. Y así como él muestra su gracia sobre sus seruidores bendiziendo a sus Hijos, assí es un testigo de su vengança sobre los iniquos, si dexa su simiente en maldición» (p. 50).

La incapacidad humana llevaría inevitablemente al castigo divino; y esto no deja resquicio para ninguna queja. Parece que aquí Calvino se dejó llevar por su convencimiento radical, y no tuvo demasiado en cuenta el precioso capítulo 18 de Ezequiel, que recoge la respuesta misericordiosa de Dios, quien no castigará a unos por otros, a los hijos por los padres, sino que sienta el principio de la responsabilidad personal.

3. La necesidad de las obras.- Fue éste sin duda uno de los temas más agudamente polémicos en los agrios debates teológicos del XVI, y una de las cuestiones en que no se daba una base mínima de acuerdo. $\mathrm{O}$ el hombre colaboraba con sus obras en su salvación, y resultaban necesarias (postura católica), o se salvaba exclusivamente por la fe, con independencia de las obras, que resultaban inútiles (postura luterana). Algo ha salido ya en las frases anteriormente señaladas, pero vale la pena no pasar de largo.

«Qué bien nos procede desta Fe, quando la tenemos? -Ella nos justifica delante de Dios, para hazernos obtener la vida eterna. / ¿Cómo?, ¿el hombre no se justifica por buenas obras biuiendo sanctamente y según Dios? -Si se hallase alguno tan perfecto, podríamos llamarle Iusto, pero como somos todos pecadores y indignos de presentarnos delante de Dios en su juizio, es necesario buscar quien responda por nosotros. / Pero nuestras obras son de tal manera reprouadas que no puedan merecer gracia delante de Dios? -Ellas

26 La expresión de la versión de 1559 resulta algo más clara: «Si consideramos la condición del linage humano, será suelta la question...». «Suelta», como equivalente de «resuelta», se aproxima a la expresión francesa «cette question sera vidée». 
son naturalmente tan viciosas que no solo no pueden agradar a Dios, pero él las condemna todas» (p. 40-41).

Junto a las afirmaciones anteriores, Calvino opta por una postura que se mueve entre la católica y la luterana, si bien enraizada en la incapacidad humana: «Pero, pues que Dios nos ha vna vez rescebido, ¿las obras que por su gracia hazemos, no le plazen? -Sí, porque él las acepta liberalmente, y no por la propia dignidad dellas» (p. 42), a lo cual añade poco más adelante:

«¿Tú no entiendes con esso que las buenas obras de los fieles sean inútiles? -No, porque Dios ha prometido de remunerarlas largamente, tanto en este mundo como en el otro. Mas todo esso procede del amor gratuito que nos tiene, el qual nos muestra sepultando todas nuestras faltas, para no tener memoria dellas» (p. 43).

Las obras humanas no son enteramente inútiles, porque Dios ha decidido tenerlas en cuenta, pero no porque valgan algo por sí mismas. Además, es voluntad de Dios que el creyente realice obras buenas como expresión y consecuencia de su fe:

«Pero, ¿podemos nosotros ser justificados creyendo sin hazer buenas obras? -Es impossible, porque creer en Iesu Christo es recebirle tal qual él se nos da. Él, pues, nos promete no sólo librarnos de la muerte, y ponernos en la gracia de Dios, su padre, por el merecimiento de su innocencia, pero también de regenerarnos por su spiritu para hazernos biuir sanctamente» (p. 43).

4. La palabra de Dios.- Ha salido ya la afirmación fundamental de que nos justificamos por la fe en Jesús, pero esa fe se nos hace presente por medio de su palabra:

«¿Cómo conocemos esso? -Por su palabra, en la qual nos declara su misericordia en Iesu Christo...» (p. 11).

Cuando comienza la cuarta parte del catecismo, con una pregunta simple del ministro en que propone avanzar en la materia, la edición francesa de 1545 , la castellana de 1550 , y la francesa de 1552 no dejan entrever que se ha pasado a otra cuestión más que por los encabezamientos de las páginas, que advierten «De la palabra de Dios» (De la parolle de Diev); por el contrario, la edición castellana de 1559 sí intercala en el texto un epígrafe: «De la Palabra, y de los Sacramentos de Dios» (p. 113), además de señalarlo, como las otras, en el encabezamiento correspondiente. En este punto aparece una pregunta que recoge la valoración expresa que concede a la palabra de Dios: 
«Quál es el medio para peruenir ${ }^{27}$ a vn tal bien? -El nos dexó su sancta palabra, la qual nos es como vna entrada en su Reyno Celestial» (p. 93).

La consecuencia del aprecio por la palabra de Dios, así manifestado, es que en el catecismo se acude a la palabra de Dios de forma clara y directa a lo largo de toda la obra. Es un recurso normal para exponer la fe, a diferencia del mutismo en que incurrieron numerosos catecismos católicos. No deja de llamar la atención en este punto la invitación a considerar que es insuficiente la lectura individual de la palabra de Dios, que se complementa con la lectura colectiva:

«¿Abasta que cada vno lea en su casa, sin que todos juntamente oyan vna Doctrina común? No, sino que mientras Dios da el medio, se empleen en lo vno y en lo otro» (p. 94).

Curiosa propuesta que parece poner sordina a la interpretación libre de la biblia, por medio de una doctrina común para todos los del mismo grupo de creyentes; se había criticado que la Iglesia católica imponía una interpretación y privaba a cada uno de libertad, y aquí se incurre en el mismo proceder. Me ocuparé luego más ampliamente del empleo de la palabra de Dios; ahora basta con dejar constancia de su importancia, y del puesto que ocupa en el catecismo.

5. Los sacramentos.- Como he indicado, la cuarta parte del catecismo versa sobre la palabra y los sacramentos; pero no se trata, como se podría pensar sin consultar la obra, que funde dos cuestiones en la cuarta parte de la obra. Más bien se trata de todo lo contrario, como evidencia la siguiente pregunta:

« ¿No ay otro medio sin la palabra ${ }^{28}$, por el qual Dios se nos comunique? -Él adjuntó los Sacramentos a la predicación della» (p. 95).

Los sacramentos son el complemento de la palabra, y por ambos medios Dios se pone en contacto con el hombre para hacer viable su salvación. Palabra y sacramentos van unidos, y de aquí que ambos se incluyan en

27 «Pervenir» es la forzada versión castellana del «parvenir», que consta en la edición francesa. La versión castellana de 1559 suaviza la frase: «¿Por qué vía podemos venir a tan grande bien?».

28 De nuevo aparece una traducción excesivamente dura. El texto francés dice: «N'y at-il point d'autre moyen outre la Parole par lequel Dieu se communique à nous?». «Outre» ha sido traducido por «sin» en la versión de 1550; en la de 1559 figura como «fuera de la palabra»; ninguna ha elegido la traducción «además de», incluyente, en lugar de los giros empleados, con sentido excluyente. 
la cuarta parte del catecismo, si bien destacan más por su tratamiento y extensión las preguntas que dedica a los sacramentos.

Aunque en el catecismo no figure en ningún lugar el principio luterano de aceptar únicamente lo que consta en la escritura (Sola Biblia), es claro que guía los pasos de la Reforma; Calvino acepta únicamente dos sacramentos, el bautismo y la cena. Antes de exponer cada uno de ellos, habla en general de los sacramentos y presenta razones para justificar su conveniencia. Da un argumento muy valioso para recibirlos,

«porque qualquiera que se abstiene voluntariamente deste vso, pensando que no le es necessario, menosprecia a Iesu Christo, desecha su gracia y amortigua su sancto Spiritu» (p. 97).

Justamente al precisar la comunicación de la gracia - también motivo de discusión teológica en el XVI - propone una dificultad: la de que los sacramentos los reciban indistintamente buenos y malos, y ahí aparece el concepto hondo de sacramento:

«Pero, ¿qué certidumbre de gracia pueden dar los Sacramentos, pues que buenos y malos les reciben? - Aunque los malos con su incredulidad, anihilan ${ }^{29}$ la gracia que por medio de los Sacramentos se les presenta, no se sigue que la propiedad dellos sea tal. / ¿Pues quando produzen ellos su effecto? - Quando los recebimos con fe, buscando en ellos solamente a Iesu Christo y su gracia» (p. 97-98).

El que los sacramentos produzcan por sí mismos su efecto, con independencia de la fe de quien los recibe ("ex opere operato"), o que estén condicionados para ello por la fe de quien los recibe ("ex opere operantis") fue un punto de inflexión que distanció las posturas de católicos y no católicos. Para el catecismo, lógicamente, los sacramentos están condicionados por la fe de la persona que accede a ellos. Por si aún no quedara suficientemente clara la postura, la pregunta siguiente da por sentado que en los sacramentos no hay virtud alguna, sino que son únicamente señales.

«Por qué dizes tu que en ellos deuemos buscar a Iesu Christo? - Para dar a entender que no es necessario de detenernos en señales terrenas, para en ellas buscar nuestra salud, ni nos conuiene ymaginar que en ella aya alguna virtud encerrada, pero al contrario deuemos tomar el señal por vna guia que nos ayuda y lleua derechamente a Iesu Christo nuestro Señor, para en él buscar salud y todo bien» (p. 98).

\footnotetext{
29 Por aniquilan, hacen nulo.
} 
Es lógico que en tiempos agitados, la consideración sobre los sacramentos girara en torno a si son señales, y sólo señales, y no fueran capaces de reconocer que el verdadero planteamiento enriquecedor, para católicos, como para reformados, es el encuentro personal con Cristo.

6. La Iglesia. Cuando hace la exposición del credo, la cuarta parte aborda la cuestión de la Iglesia, como era lógico. Ofrece la siguiente definición de Iglesia:

«¿Qué es la Yglesia Catholica? - Es la compañía de los fieles que Dios ha ordenado y elegido para la vida eterna» (p. 34) (La versión de 1559, más libre y un poco más redundante, dice: «Es vn cuerpo y compañía de fieles, a los quales ha Dios ordenado y elegido para la vida eterna»).

Prima la elección de Dios por encima de cualquier otro criterio. Se podía haber ofrecido una definición de iglesia desde muchos puntos de vista, pero Calvino ha optado por éste, que muestra la iniciativa divina, dada la incapacidad humana para la salvación. A continuación, el catecismo pregunta si es necesario aceptar este artículo del credo, y en la respuesta, vuelve a aparecer una especie de segunda definición o descripción de iglesia:

«¿Es necessario creer en este artículo? - Sí, si no queremos hazer la muerte de Iesu Christo y todo lo que hauemos ya recitado vano. Porque el fructo que procede de todo ello es la Yglesia» (p. 34).

La iglesia es, pues, el resultado de la acción salvadora emprendida por Dios con la muerte y resurrección de Cristo; no aceptar las consecuencias en la iglesia, es negar el origen de donde dimana.

Cuando explica la nota de «santa», aplicada a la iglesia, surge de nuevo la elección divina:

«Porque aquellos a quien Dios ha elegido, les justifica y purifica con sanctidad y innocencia, para hazer resplandecer en ellos su gloria. $\mathrm{Y}$ assí Iesu Christo nuestro Señor, hauiendo redemido su Yglesia, la sanctificó para que fuesse gloriosa y sin manzilla alguna» (p. 35).

Y, además, señala sin rodeos, que esa iglesia, fruto de la elección divina, tiene una realidad visible y no se queda sólo en algo invisible y de orden espiritual:

«¿No podríamos conocer esta Yglesia de otra manera sin creerla? - Yglesia visible de Dios ay, según las señales que nos ha dado para conocerla. Pero aquí hablamos propiamente de la compañía de aquellos que Dios ha elegido para saluarles, la qual no se puede enteramente ver al ojo» (p. 36). 
En este apartado se percibe con claridad una gran diferencia entre Calvino y Lutero, pues Calvino acepta e insiste en la necesidad de una congregación organizada a la que reconoce con el nombre de iglesia.

Cuando el catecismo habla de la iglesia, según el sentir de los reformadores, no se está refiriendo, como es natural, a la iglesia católica, sino a la realidad constituida por los creyentes, con independencia, e incluso rechazo de las formas visibles, con las instituciones, normas y reglamentos con que la iglesia había llegado a los inicios del siglo XVI. A la vista de los excesos más llamativos y palpables de la curia romana, tratan de llevar a cabo otra propuesta diferente que elimine esos mismos abusos. Por eso tiene una notable fuerza para su momento - y una rabiosa actualidad para nuestros días - la pregunta acerca de la perfección y de la santidad en la iglesia:

«¿Pero la sanctidad que tu atribuyes a la Yglesia, es perfecta agora? - No lo será mientras batallare en este mundo. Porque siempre ay reliquias de imperfection las quales duraran hasta que sea enteramente vnida con Iesu Christo, su cabeça y sanctificación» (p. 36).

Una iglesia siempre imperfecta y siempre necesitada de renovación ${ }^{30}$.

Sin referirse expresamente ni mencionar la palabra Iglesia, lo da a entender cuando, más adelante, al hilo de la cuestión del cumplimiento de la ley que Dios da, la pregunta vuelve a la cuestión de los «fieles», mencionados en la definición de Iglesia:

«¿Hablas de todos los hombres, o de los fieles solamente? - El hombre que no es regenerado por el Spiritu de Dios, no podría començar a hazer la menor de las cosas que aquí se contienen. $Y$ aunque se hallasse alguno que hiziesse alguna parte della, no por eso sería quito. Porque nuestro Señor declara que todos aquellos que no harán enteramente lo que en su Ley se contiene, serán mal$\operatorname{ditos}^{31} \gg($ p. 68-69).

30 Cuánto se parecen esas afirmaciones del catecismo a las que, cuatro siglos después, formula el Concilio Vaticano II: «La Iglesia, abrazando en su seno a los pecadores, es a la vez santa y siempre necesitada de purificación, y busca sin cesar la conversión y la renovación» (Lumen gentium, 8).

31 Se aprecia aquí la dependencia de la versión de 1550 respecto al texto francés; la edición francesa de 1545 dice en esta pregunta: «L'homme qui n'est régénéré de l'Esprit de Dieu ne pourrait commencer à faire le moindre point qui y soit. Davantage, encore qu'il s'en trouvât un qui en fit quelque partie, si ne serait-il pas quitte pourtant. Car notre Seigneur dénonce que tous ceux qui ne parferont entièrement le contenu d'icelle seront maudits». Al contrario, la versión castellana de 1559 se expresa así: «El que no fuere renouado por el Spiritu de Dios, no podrá ni aun començar a hazer el más pequeño punto de la ley. Allende desto, ya que alguno se hallase que en alguna manera obedezca a la ley, no por esso aurá cumplido delante de Dios. Porque sentenciados tiene por malditos a todos los que no cumplieren perfectamente quanto en ella se contiene» (p. 87). 
En esta respuesta, excluye de forma notoria a los que no son de los fieles, que están absolutamente incapacitados para la más mínima acción aceptable a Dios.

Para finalizar este apartado es imprescindible recordar el sentido excluyente que el catecismo da a la iglesia, como elemento visible, y como medio de salvación:

«¿Assí fuera de la Yglesia no ay sino damnación y muerte? - Cosa es muy aueriguada. Porque todos aquellos que se apartan de la comunicación de los fieles, para hazer secta aparte, no deuen esperar salud mientras estuuieren separados» (p. 37).

Se trata del viejo adagio «extra Ecclesiam, nulla salus», que, en los tiempos de la Reforma, cada una de las confesiones se aplicaba a sí misma, mientras denominaba con desprecio sectas a los demás grupos. Cada uno se arrogaba la interpretación genuina del evangelio y por lo tanto excluía a los demás. El catecismo examinado no constituye una excepción.

7. La Iglesia católica. La ruptura de la unidad condujo a las mutuas acusaciones de infidelidad con relación a lo que el evangelio señalaba. Pero al topar con la afirmación del credo, era preciso decir algo sobre la nota de católica señalada a la Iglesia. Ya hemos visto que en la pregunta o definición sobre la iglesia, el catecismo propone, sin rodeos, la calificación de católica. Después de preguntar por la santidad, la pregunta se vuelve a este aspecto en particular:

«¿Qué quiere dezir esta palabra Catholica o vniuersal? - Ella significa que, como no ay sino una cabeça de los fieles, assí todos deuen de ser vnidos en vn Cuerpo. De manera que no ay muchas Yglesias, sino vna sola, la qual está derramada por todo el mundo» (p. 35).

Pregunta y respuesta son irrreprochables, y podrían ser firmadas por cualquiera de los grupos y confesiones cristianas. Y, contrastada con las propuestas del Nuevo Testamento sobre la unidad, hay que reconocer el pensamiento más adecuado sobre el sentido de catolicidad única. Lo malo es que todos cuantos firmaban esta declaración se manifestaban inmediatamente en contra de los demás grupos, para autoproclamar el sentido genuino y legítimo del suyo en particular ${ }^{32}$.

El catecismo lo hace así también. La primera pregunta, sobre la iglesia, tiene el adjetivo de «católica», simplemente; la pregunta reproducida tiene

\footnotetext{
32 Procede recordar que lo mismo sucede en el Common Prayer Book de la Comunión Anglicana, cuando propone el credo.
} 
el doble adjetivo de «católica o universal»33. Es válido hacerlo así, pues ése es precisamente su sentido, pero no es posible olvidar que las denominaciones que empleó cada confesión cristiana trataban de identificarlas y singularizarlas por contraste con el resto de los grupos ${ }^{34}$.

8. Pastores y ministros. La cuestión deriva lógicamente de lo anterior, porque aceptar una iglesia visible en ciertos aspectos supone disponer de una determinada organización, con unas personas que asumen la responsabilidad de ciertos cargos y tareas. Sin embargo, el catecismo de Calvino no lo aborda en este punto, a continuación de la Iglesia, sino en la cuarta parte - De la palabra y de los sacramentos - relacionado con la proclamación de la palabra:

"¿Conuiene, pues, que aya en ella [la Iglesia] Pastores? - Sí, y que sean oydos, rescibiendo de sus bocas la doctrina de Dios, con toda humildad. Porque los que les menosprecian y dexan de oyrles desechan a Iesu Christo, y se apartan de la compañía de los fieles» (p. 94-95).

En la pregunta siguiente, emplea el otro sustantivo de «Ministros» como equivalente al de Pastores que ha salido ya: «... y él [Cristo] ordenó los Ministros de la Yglesia para enseñarnos en su nombre» (p. 95). La organización eclesiástica llevada a cabo por Calvino en Ginebra estableció cuatro categorías de personas al frente de la comunidad: pastores, doctores, ancianos y diáconos. Los primeros, a los que se refiere esta pregunta, tenían como función predicar, instruir, exhortar o reprender, según procediera al anunciar la palabra de Dios; además, administrar los sacramentos; $\mathrm{y}$, como tercera función asignada, la de confortar a los enfermos. También aquí se aprecia la diferencia entre Calvino y Lutero, quien, al exaltar el sacerdocio común, universal, prescinde de todo tipo de ministerio organizado, como reacción frente al sacerdocio ministerial de los católicos.

9. Las imágenes. Cuando en la segunda parte del catecismo aparece el tema de la obediencia a Dios por el cumplimiento de la ley, se acude -como

33 Sin embargo, la versión de 1559 , desde el mismo recitado del credo, cambia el adjetivo, y aparece únicamente la expresión «Creer una sancta Yglesia vniuersal», aunque en la otra pregunta incluya ambos: « $i$ Qué quiere dezir este nombre de Catholica o vniuersal?».

${ }^{34}$ No es posible olvidar que, cuando en 1054 se produjo la ruptura con el Cisma de Oriente, mientras unos se apelaron «los de la genuina fe» (los ortodoxos), los otros se aplicaron la nota de «universales» (católicos), para diferenciarse, y a la vez, para identificarse. Otro tanto sucedió en el XVI, cuando los «protestantes» se llamaron así porque «protestaron»o expresaron los convencimientos irrenunciables de su fe (Dieta de Spira, 1529). 
no podía ser de otra forma- a los libros del Éxodo y del Deuteronomio ${ }^{35}$. Reproduce, por consiguiente, el segundo mandamiento veterotestamentario, sobre la prohibición de imágenes, y a continuación pregunta:

«¿Quiere defender totalmente las ymágines?36 - No, sino aquellas que se hazen a su figura, o para adorarlas».

El catecismo distingue entre el Dios espiritual e invisible, y la imagen, muerta, corruptible y visible, que en ningún caso habría de ser confundida con la idea de Dios. La otra matización destacable que aparece expresamente en el catecismo consiste en el abuso a la hora de adorar a Dios, por la cuestión de las imágenes:

«¿Qué manera de adoración se condemna aquí? - El presentarse delante de vna ymagen para hazer oración, hincarse de rodillas delante della, o hazer alguna otra señal de reuerencia, como si allí Dios se nos mostrase» (p. 48).

Es claro que el catecismo apunta a una práctica muy extendida por parte de los cristianos, que estima como abuso, y trata de erradicar al señalarla como tal.

Pero había otra vieja polémica, la de los iconoclastas, que había sembrado de zozobra la cristiandad en su momento. Diferenciar entre la representación y lo representado no constituía problema para personas formadas; pero la identificación entre lo uno y lo otro era el riesgo de la gente sencilla; y de ahí la práctica abusiva que el catecismo trata de rectificar ${ }^{37}$.

A pesar de todas esas cautelas, no hay más remedio que recordar la distancia entre las afirmaciones moderadas del catecismo, y lo que después sucedió en los momentos de exaltación reformada, con asalto a los templos

35 Con todo, las referencias de los ladillos al texto bíblico, muestran una gran divergencia: La versión castellana de 1550 remite a Ex. 32 y 34 y a Dt. 4 y 10; la versión castellana de 1559 suprime dos citas, y remite sólo a Ex. 34 y Dt. 10. La edición francesa de 1545 (quizá retocada en este aspecto en la versión moderna que manejo) apunta a Ex. 20,2-3 y Dt. 5, 6-7, mientras que la edición antigua, de 1552, hace las mismas citas que la versión castellana de 1550: Ex. 32 y $34 ;$ Dt. 4 y 10.

36 «Defender» tuvo el sentido castellano de prohibir - hoy en desuso-, equivalente al francés, que aparece en las ediciones francesas consultadas: «défendre». La versión castellana de 1559 , más clara, elige el verbo «vedar», a la vez que hace una extensión sobre las pinturas, asimiladas a las imágenes: «¿Veda del todo que no se pinten ni se hagan de talla algunas imágines?».

37 Lutero siguió en su exposición de los mandamientos la expresión tradicional en la Iglesia, que omitía la referencia al mandato sobre las imágenes en segundo lugar; esto lo hace tanto en el Catecismo mayor, como en el breve. Calvino, al contrario, es literal con relación al texto bíblico, si bien, como es posible apreciar, no existe en sus palabras una prohibición absoluta, y trata de erradicar el abuso. 
y destrucción de numerosas y valiosas imágenes. La concesión medieval más equilibrada y sopesada afirmaba que las imágenes y pinturas eran la biblia de los analfabetos, y que en ellas captaban lo que les estaba vedado en los libros. Sin decirlo expresamente, Calvino se sitúa en esa corriente moderada ${ }^{38}$, cosa que no hicieron sus seguidores inmediatos.

10. Bautismo de niños. El catecismo no deja duda en este punto, y lo explicita para no dar lugar a interpretaciones en uno $u$ otro sentido. Lo hace en la cuarta parte, después de hablar de los dos sacramentos aceptados, bautismo y cena. A propósito del primero plantea otra serie de cuestiones, y al llegar a este punto, dice:

«Pues esso [la fe] se requiere, ¿cómo baptizan los niños? - No dezimos que la Fe y el arrepentimiento deuen siempre preceder la recepción el Sacramento, porque esso se requiere solamente en los que son capables [= capaces] dello. Abasta, pues, que los niños produzgan y muestren el fructo de su Bautismo siendo venidos a edad de conocerse. / ¿Cómo me mostrarás tú que en esso no aya inconuiniente? - Porque la circuncisión era también Sacramento de Penitencia como Moysen y los Prophetas declaran, y Sacramento de Fe como dize sanct Pablo, y todavía Dios no excluyó della los niños» (p. 103).

Con toda la importancia que otorga a la fe, el catecismo no la presenta como condición previa, temporalmente hablando, sino como algo exigible en los que son capaces de ello. Por otra parte, la comparación con la circuncisión abre la puerta a los niños, que eran introducidos de esa forma a los ocho días preceptivos en la asamblea de Israel; por lo tanto los niños cristianos son introducidos por el bautismo en la comunidad de cristianos; de proceder de otra manera, se desvirtuaría la entrega de Cristo.

La propuesta del catecismo, nítida, no deja lugar a la duda ${ }^{39}$. Lutero no había entrado en esta cuestión en sus catecismos. Pero era un punto de fricción entre los reformados: los anabaptistas, reunidos en torno a Nicolás

\footnotetext{
${ }^{38}$ En el catecismo amplio o Instruction de la foy..., dice: «...Et davaintage, il deffende que nous ne honorions aucune image pour religion. Apprenons doncq de ce commendement que le service et honneur de Dieu est spirituel, car comme il est Esperit, ainsi requiert-il estre servi et honoré en esperit et verité» (ANNETE ZILLENBILLER - MARC VIAL [eds.] Instruction et confession de foy dont on use en l'Eglise de Geneve. Catechismus seu christianae religionis institutio Ecclesiae Genevensis, Genève, Librairie Droz, 2002, 15).

39 En el catecismo amplio o Instruction de la foy..., aparece al respecto una frase breve, pero clara: «Comme ainsi soit doncques que principalement par les baptesme l'alliance du Seigneur soit conformée avec nous, à bon droit nous baptisons noz enfants, estant participans de l'alliance eternelle par laquelle le Seigneur promect qu'il sera Dieu non pas seulement de nous, mais de nostre semence» (Ed. citada, 97).
} 
Storch y a Thomas Münzer (1522), negaban la práctica de bautizar a los niños por carecer de fe personal. Posteriormente, con otro nombre similar, las corrientes baptistas comparten el mismo criterio.

11. Predestinación. Es un punto capital del pensamiento calvinista, y, como no podía ser de otra manera, el catecismo tenía que recogerlo en sus páginas. Ahora bien, sorprendentemente, no resulta un apartado ni llamativo, ni ampliamente tratado. Aparece discretamente, como algo natural, a propósito de las preguntas sobre la Iglesia, reproducidas más arriba. Así, cuando habla de «aquellos que Dios ha elegido», a los que justifica y santifica, o cuando, en la definición de Iglesia se centra en «los fieles que Dios ha ordenado y elegido». Lo reitera cuando habla de la condición visible de la iglesia como grupo organizado, aunque, a renglón seguido, añade: «pero aquí hablamos propiamente de la compañía de aquellos que Dios ha elegido para saluarles».

Llama poderosamente la atención esta especie de discreto silencio sobre un tema central, que aparece - cierto - tan sólo como si estuviera insinuado. Pero encuentro para ello una doble justificación. Por un lado, acaso porque no es preciso insistir mucho en lo que resulta evidente, y el catecismo da por sentado que esto es así, y que quienes se han de salvar o condenar están ya establecidos y situados en el pensamiento divino. Por otro lado, el hecho de evitar la polémica en el catecismo, destinado al pueblo sencillo; provocarla podría ser contraproducente, o, en el mejor de los casos, un elemento de turbación. De este modo, dándolo por sentado, y presentándolo de forma suave, sería más fácil obtener un asentimiento; no produciría rechazo si no se hacía problema. Muy al contrario, en la Institutio, la obra magna de Calvino, es el tema central de sus afirmaciones, especialmente con el término de «elección».

\section{ALUSIONES A LA IGLESIA CATÓlICA}

Ya he manifestado que el estilo y tono del Catecismo es sereno y respetuoso, carece de elementos que susciten la burla, agresiones o desprecios. No sucede así en la Institutio, donde con frecuencia aparecen este tipo de expresiones, como consecuencia de la voluntad de refutar a quienes no piensan como él. El Catecismo, breve y expositivo, mantiene otra línea. Ni siquiera se puede tomar por ofensiva la expresión de la Carta al Lector, en que hablaba de «singerie», como una tontada o una maldad, aunque acaso sea la expresión más ruda de toda la obra. 
Eso no impide que a lo largo de la exposición aparezcan una serie bastante clara de alusiones a lo que los católicos hacen o piensan. No menciona el adjetivo de «católicos» para referirse a otro grupo cristiano que mantenía criterios diferentes; pero, sin mencionarlo, es evidente que se está refiriendo a las prácticas católicas.

En primer lugar, cuando habla de la oración señala que las palabras han de ir acompasadas con los sentimientos, para que no se queden en algo vacío; es el momento elegido para endosar la siguiente pregunta:

«Si assí es, ¿de qué sirue la oración en lengua no conoscida? - Es burlarse de Dios y hazer del hypócrita peruerso» (p. 75) ${ }^{40}$.

Cualquier que leyera esto sabía con certeza que se estaba refiriendo a la liturgia católica, celebrada tradicionalmente en latín, mientras el resto de los reformadores habían optado por las lenguas respectivas de los países en que residían. Podría haber aducido que carecía de sentido para la persona que rezaba hacer unas preces sin entender lo que decía; pero es evidente que ése era un problema para la persona orante, pero no para el Dios al que se dirigían las oraciones.

En segundo lugar, cuando habla de la Iglesia, como hemos visto, el catecismo se refiere a los «verdaderos fieles», lo cual equivale a decir que el resto no eran sinceros y genuinos adoradores de Dios. Las disensiones llevaban de hecho a las descalificaciones. El apropiarse del carácter de verdadero fiel ponía a todos los demás en la categoría de falsos fieles. Cierto que el catecismo no dice eso, pero lo da a entender. La forma de buscar la adhesión del lector del catecismo para aglutinarlo en torno al grupo de cristianos calvinistas era la afirmación de autenticidad. La consecuencia cae por su propio peso.

En tercer lugar, cuando habla del sacramento de la cena, entra directamente en la cuestión de los dos elementos con que se celebra:

«¿Por qué hay en la Cena dos señales? - Nuestro Señor lo hizo por nuestra flaqueza, para que conozcamos que no sólo es manjar de nuestras almas, más también beurage ${ }^{41}$, y que en él sólo deuemos buscar nuestro lleno y entero

\footnotetext{
${ }^{40} \mathrm{La}$ traducción es bastante diferente en la versión de 1559: «Si esso es así, ¿qué fructo sacan los que oran en lengua estraña que no entienden? - Orar de tal manera no es verdaderamente otra cosa que vn hazer burla de Dios y vna peruersa hypocresía, de la qual deue huyr el Christiano». El texto de la versión de 1550 parece decir que convierte a Dios en un hipócrita, forzando el original francés que habla de una «hypocrisie perverse». La versión de 1559, añade de su cosecha la última frase sobre lo que no debe hacer el cristiano.

41 Defectuosa traducción, excesivamente apegada al francés «breuvage», que, en castellano tendría que haber aparecido como brebaje; acaso una errata de imprenta contribuyó aún más a la confusión. La versión de 1559 emplea el término «bebida».
} 
mantenimiento / ¿Deuen todos vsar sin differencia de la segunda señal que es el Cáliz? - Sí, según el mandamiento de Iesu Christo, contra el qual no es lícito intentar cosa alguna» (p. 109).

Los seguidores de Calvino, que habían celebrado la eucaristía hasta hacía poco al modo tradicional romano, antes de la ruptura, percibían claramente la diferencia entre lo que señalaba una y otra confesión. El hecho de no emplear el cáliz en celebraciones con mucha asistencia de comulgantes se debió a razones prácticas, fundamentalmente. Pero la simplicidad con que el catecismo exponía el argumento hacía que la iglesia católica apareciera como la falsificadora de las palabras de Cristo, al intentar otra cosa, lo cual no era lícito.

En cuarto lugar, en el mismo contexto de la cena, aparece la diferente forma de entender la muerte de Cristo, y consiguientemente la celebración de la eucaristía, como reiteración del sacrificio de Cristo (postura católica) o como sacrificio único e irrepetible (postura reformada).

« ¿Y en la señal del vino, qué tenemos? - Iesu Christo nuestro Señor nos abeu$\mathrm{ra}^{42}$ de su sangre, en tanto que la ha vna vez derramado por el precio y satisffaction de nuestros peccados, para que no dudemos de rescibir el fructo della. / Según tus respuestas, la Cena nos embia a la muerte y passion de Iesu Christo para que comuniquemos en la virtud della. - Assí es verdad. Porque entonces el sacrificio vnico y perpetuo de nuestra redempción fue hecho, y assi no queda sino que nosotros gozemos dél» (p. 108).

Es sacrificio único y perpetuo, y carece de sentido repetirlo, como hacen los católicos, puesto que, como afirma en la pregunta siguiente, Cristo es el único sacerdote. De hecho, la denominación de los cargos en la comunidad ginebrina rehuyó la palabra «sacerdote», para distanciarse de los católicos que la usaban. Pero la cuestión fundamental no estaba tanto en las personas que estaban al frente de la comunidad, sino en el hecho de entender la eucaristía como sacrificio de Cristo, o como simple recuerdo y memoria.

En quinto lugar, resulta inevitable reconocer que hace una alusión a los católicos con el empleo del adjetivo «católica» aplicado a la Iglesia. Cierto que es la expresión del credo apostólico, de la que ninguna confesión era dueña en particular, pero el hecho de la diferenciación de grupos obligó a buscar calificativos para cada uno de ellos. Ya presenté las formas en que se expresaban las dos versiones, y cómo la versión de 1559 es más radical, puesto que evita a toda costa la palabra «católica», tanto en el formulario del credo, puesto al comienzo del catecismo, como en la recitación del

42 Como he señalado en la nota anterior, tendría que haber puesto nos «abreba». 
mismo en la pregunta correspondiente (p. 24-25), en tanto que el resto de las versiones (la castellana de 1550, y las francesas de 1545 y 1552) utilizan sin problema la expresión «católica», que después explican en el sentido etimológico de universal43. De esta forma, la alusión, inexcusable, quedaba suficientemente matizada para los lectores del catecismo.

En sexto lugar, veladamente, pero no tanto como para que no fuese entendido, cuando aborda el tema de las imágenes - ya analizado - lo condensa en la adoración a Dios «para apartarnos de todas supersticiones y cerimonias carnales» (p. 49). Con ello está dando a entender, con un sentido de desprecio, que las ceremonias que realizaba la Iglesia católica en torno a las imágenes, o con presencia de ellas, eran formas viciadas de religión, que debían ser desechadas. Los lectores del Catecismo tenían que entenderlo sin ningún tipo de dificultad.

Las ocasiones señaladas hacen una clara alusión a los católicos, y los lectores del catecismo no podían dejar de entenderlo, porque era algo que estaba en el ambiente, como tema de polémica, de enfrentamiento y de diferenciación. Afirmar un supuesto era lo mismo que negar el contrario. Y esto es lo que hace el catecismo con estas alusiones nada veladas a las prácticas católicas, con las que disiente.

\section{EL EMPLEO DE LA BIBLIA}

Ya enuncié el empleo y la relevancia que el catecismo concede a la palabra de Dios, como un recurso insoslayable para la catequesis. Pero en los tiempos en que se redactó, había una gran diferencia. Estaba en el ambiente la cuestión de la traducción de la biblia a las lenguas vulgares, y el principio luterano de que cada uno pudiera interpretarla con libertad, sin atenerse a una interpretación oficial y común. Entre los reformados, los catecismos tenían una notable riqueza de empleo de la palabra de Dios; es verdad que ésta era empleada como argumento de autoridad para refrendar posturas adoptadas, que no siempre eran compartidas por todos los gru-

\footnotetext{
43 La Declaración de Fe, llamada de La Rochelle, de 1559, válida para todas las comunidades calvinistas francesas, en su artículo $5^{\circ}$, hace expresa aceptación de los tres credos tradicionales: «Dans cet esprit, nous reconnaissons les trois Symboles, à savoir: le Symbole des Apôtres, le Symbole de Nicée, le Symbole d'Athanase, parce qu'ils sont conformes à la Parole de Dieu». Cuando pone el texto de todos ellos, en el símbolo apostólico aparece la palabra «universal»; en el de Nicea, elimina el adjetivo «una», aplicado a la Iglesia, y emplea igualmente el de «universal»; en el Atanasio, tanto al principio como al final consta la expresión «foi catholique».
} 
pos. Sirve como ejemplo lo que ha aparecido sobre la circuncisión, como fundamento, para Calvino, del bautismo de los niños, pero que no era igualmente aceptado por todos los reformadores, a pesar de acudir todos a la misma palabra de Dios.

Entre los católicos, los mejores - y normalmente más extensos - catecismos emplearon con abundancia y notable acierto la palabra de Dios como fundamento de aquello que enseñaban a sus lectores. Sin embargo, en los catecismos breves, en los que corrieron entre el pueblo llano, en los más simples, la carencia de expresiones bíblicas es desoladora. Parece que se entra en un desierto bíblico: porque aunque las enseñanzas que se transmiten podrían estar fundadas en la biblia y podrían remitir a ella, no se hace así. Da la impresión de que hay prevención en utilizarla. Basta que los luteranos y otros grupos la empleen, para que los católicos la rehuyan. Soy consciente de que estoy simplificando las cosas, pero la consulta directa de textos de uno y otro lado arroja esa sensación.

El catecismo que nos ocupa, en las dos versiones examinadas, tiene abundancia de referencias a la palabra de Dios. No me refiero únicamente a los ladillos, en que constan las citas que podían ser consultadas. Prefiero centrarme en las ocasiones en que, en el propio texto, cita y habla de la biblia con una normalidad que contrasta con el silencio católico. Son bastantes, son abundantes, y bien aducidas, como consecuencia de un conocimiento que se desea pase al pueblo creyente. Ésa fue precisamente la consecuencia principal, y más notable: mientras los católicos continuaron ignorando la palabra de Dios (no se leía en privado de forma habitual, y en la celebración se hacía en latín), los reformados disponían de traducciones que hacían posible su lectura personal y comunitaria en las reuniones cultuales.

Las ocasiones en que se alude a la palabra de Dios son tantas que me limito a enumerarlas sin comentario particularizado:

1.- «¿Cómo conoscemos esso [Dios padre y salvador] - Por su palabra en la qual...» (p. 11).

2.- «... a causa de Iesu Christo que es la Palabra eterna engendrada del...» (p. 14).

3.- «... ungido ... para dar fin a todas las Prophecías y reuelaciones» (p. 19).

4.- «... y a causa desta comunicación dize la Scriptura, el primero nacido entre muchos hermanos» (p. 21).

5.- «... para ser simiente de Dauid, como hauía sido prophetizado» (p. 21).

6.- «Sí, como el Apóstol lo muestra diziendo que fue colgado del madero» (p. 25).

7.- «... estuuo en Angustia marauillosa, que sanct Pedro llama los dolores de la muerte» (p. 26). 
8.- «gritando dixo: Dios mío, Dios mío, ¿por qué me has desamparado?» (p. 27).

9.- «... para verificar la prophecia de Isayas que dize: Fue tocado de la mano del Señor» (p. 27).

10.- «Tú no entiendes, pues, sino lo que sanct Pablo dixo: Que fue constituido cabeça de la yglesia» (p. 31).

11.- «Sanct Pablo responde a esta question diziendo que los que biuirán entonces serán súbitamente mudados...» (p. 32).

12.- «...vn cierto y firme conocimiento del amor que Dios nos tiene, según que su Euangelio lo muestra» (p. 39).

13.- «La Escriptura nos enseña que es vn don singular del Spiritu sancto» (p.39).

14.- «Porque creyendo y rescibiendo con verdadera confiança las promessas del Euangelio...» (p. 42).

15.- «...Dios nos las presenta por el Euangelio...» (p. 42).

16.- «La doctrina del Euangelio se comprehende en dos palabras, a saber es, Fe y Penitencia» (p. 44).

17.- «el número de siete significa en la Escriptura perfición» (p. 56).

18.- «Y assí sanct Pablo dize que les es ministerio de muerte y damnación» (p. 69).

19.- «¿De qué siruen, pues, todas las amonestaciones, enseñamientos, mandamientos y exhortaciones que los Prophetas y Apóstoles hazen? (p. 70).

20.- «y también tenemos la declaración dello en toda la sancta Scriptura...» (p. 70-71).

21.- «... y por esso dize Sanct Pablo que la derecha inuocación procede de la fe» (p. 75-76).

22.- «porque la Scriptura nos dize que demandemos con $\mathrm{Fe}$, y que nos será otorgado» (p. 76).

23.- «Y de hecho la Scriptura nos certifica que queriendo el más perfecto de los hombres allegar a Dios vn punto para justificarse...» (p. 86).

24.- «Como las palabras de que Iesu Christo vsó nos le muestran...» (p. 87).

25.- «Todos los loores y actiones de gracias contenidas en la Sancta scriptura» (p. 92).

26.- «Lo que atestigua Jesu Christo, verdad infallible» (p. 91).

27.- «Él nos dexó su sancta palabra, la qual nos es como vna entrada en su Reyno Celestial» (p. 93).

28.- «¿Dónde tomas tú esta palabra? - Como se comprehende en las sanctas scripturas» (p. 93).

29.- «Porque la circuncisión era también Sacramento de Penitencia, como Moysén y los Prophetas declaran...» (p. 103).

30.- «... y Sacramento de fe, como dixo sanct Pablo» (p. 103).

31.- «Por la predicación del Euangelio la tenemos también, como Sanct Pablo dize» (p. 107).

32.- «¿Cómo deuemos vsar dél? - Como dize Sanct Pablo quel hombre se prueue a sí mismo» (p. 111). 
Son treinta y dos ocasiones en que el texto del catecismo remite a la palabra de Dios; lo hace con alusión genérica, y también concreta y específica, buscando y controlando la cita exacta. Como síntesis de todas ellas, bien vale la pena, por su belleza, resaltar, por medio de la repetición, la frase que condensa todas, por la importancia misma que concede a la palabra de Dios: «Él nos dexó su sancta palabra, la qual nos es como vna entrada en su Reyno Celestial».

Sin embargo, llama poderosamente la atención que, pese a un uso tan abundante de la biblia, en la edición de 1550, al resumir los mandamientos, en el amor a Dios y al prójimo, no remita al texto bíblico, bien conocido. Tampoco lo hacen la edición francesa de 1545, ni la francesa de 1552; por el contrario, la castellana de 1559 remite en ladillo a Mt. 22, lo que evidentemente es un añadido con vistas a mejorar la edición en una pequeña omisión de las precedentes. También resulta chocante la atribución a Jesús de una frase no recogida en el evangelio: «Por la predicación del Euangelio la tenemos también, como Sanct Pablo dize, en la qual nuestro Señor Iesu Christo affirma que somos huesso de sus huessos y carne de su carne...» (p. 107). La referencia del ladillo remite a Ef. 5, 30, que habla de la unión de la Iglesia con Cristo, como esposa suya que es, pero la expresión - no el sentido - no aparecen así como expresión del mismo Jesús.

\section{EL APÉNDICE SOBRE LA CENA}

La versión castellana de 1559, posiblemente siguiendo los pasos de la francesa de 1552, incluye un apéndice - entre otros - con un sentido catequético notorio. Aparece titulado como «La forma que se tiene en preguntar y examinar a los pequeños antes de ser admitidos a recebir la Cena de nuestro Señor Iesu Christo». El diálogo con el que está construido discurre entre el Maestro y el Discípulo, como también ocurre en el catecismo.

Este apéndice tiene varias características. Para empezar es un resumen condensado de las enseñanzas que aparecen en el catecismo, por lo que no hay, por principio, novedades en su contenido. Además, para mayor facilidad sigue el mismo esquema y orden; es decir, que conociendo el orden del catecismo, se sigue a la perfección también el del apéndice examinado. Sin embargo, la tercera nota es que emite algún juicio más duro en la expresión que el que aparece en el catecismo; se percibe una apreciación diversa en uno y otro. Volveré sobre ello a continuación.

Pero la cuarta nota merece la pena ser tratada aparte: introduce cambios. He indicado que sigue la edición francesa de 1552, que contiene el apén- 
dice, pero también pudo seguir otra edición francesa entre 1552 y 1559 , en que se publicó. No puedo asegurar que no hubiera cambios de una edición a otra, pero sospecho que los cambios se producen en la versión castellana. Contrastada ésta con la edición de 1552, francesa, la redacción castellana de 1559 introduce una serie de cambios notables. El más importante de todos es que de las 21 preguntas de la edición francesa, pasa a 49 preguntas en la versión castellana. Hay que matizarlo un poco más, porque de las 21 preguntas originales, sólo reproduce 20 (Elimina la pregunta: «Ministre: Et qui pries-tu? / L'enfant: Dieu»). Por lo tanto lo que hace es añadir 29 preguntas a las 20 originales que reproduce, más la supresión de una pregunta. Además, en algunas preguntas hace añadidos por su cuenta, con lo que la pregunta original subsiste, pero alterada, y no siempre era factible a todos saber diferenciar lo uno de lo otro. Pongo un ejemplo de esta alteración. La pregunta francesa decía: «Ministre: En qui crois-tu? / L'enfant: En Dieu le Pere, et en Jesus Christ son Fils, et au sainct Esprit», en tanto que la pregunta alterada dice: «Maestro: Pues teneys la fe por señal de ser Christiano: dezidme agora, En quien creeys? / Discípulo: Creo en Dios Padre, y en Iesu Christo su Hijo, y en el Spiritu Sancto: en quien tengo toda la confianza de mi salud, y a quien me voy siempre por socorro en todas mis necessidades». Es evidente que no dicen lo mismo. Así como en el cuerpo del catecismo, en las 373 preguntas centrales hace algunos añadidos por redundancia o por buscar una expresión más fluida o más florida, en la carta inicial introdujo sus numerosos añadidos, y lo mismo realizó en el apéndice sobre la forma de recibir a los niños en la Cena. Respetuoso con el cuerpo de doctrina, no se priva de hacer sus retoques en lo que le parece procedente al principio y al final.

En este apéndice aparecen algunos juicios más severos -o más concisos- que en el cuerpo del catecismo. Son dos las ocasiones en que aparece esto: la primera versa sobre la práctica de los mandamientos de Dios: «Deuemos seruirle según sus mandamientos, y no según las tradiciones de los hombres» (p. 154). Parecen resonar las palabras de Pedro cuando se explicaba ante el Sanedrín para justificar la curación del tullido de Jerusalén (Hch. 4, 19). Pero no es preciso remontarse tan lejos, puesto que en la carta de Calvino que abre la Institutio, destinada a captar la benevolencia de Francisco I de Francia, aparece una expresión con la que el reformador de Ginebra se justifica:

«Nous estimons être très raisonnables de préférer les commandements de Dieu, qui est la Vérité même, aux commandements des hommes, qui, de leur nature, sont enclins au mensonge et à la vanité».

La segunda ocasión en que figura otro juicio conciso del apéndice, y que contiene también una divergencia entre católicos y calvinistas es la pre- 
gunta « ¿Ay otro abogado, o tenemos necessidad de otro que deste para delante del Padre? - No ay otro, ni tenemos necessidad de otro. Porque como no ay más que vn Redemptor, que es Iesu Christo, assí no ay ni puede auer más de vn Abogado y Medianero entre Dios y los hombres, que es él mismo» (p. 157). La exclusión de cualquier otra mediación era una nota de los reformados, que acudían a la biblia para legitimarla. La radicalización estriba en que las noticias sobre Dios siempre nos llegan mediatizadas a través de personas, instituciones, testigos, que nos ponen en contacto con él. Pero cuando surgió este catecismo, y su apéndice, no había demasiada serenidad para matizar las afirmaciones contundentes.

Las preguntas añadidas por Juan Pérez de Pineda al apéndice caminan también en esa línea de una mayor dureza y juicio más severo que lo que había expresado el apéndice original. Las cuatro muestras que siguen manifiestan que el corrector no sólo añade lo que estima procedente, sino que además transmite una carga de rechazo notable. Ésta es la primera muestra de las preguntas añadidas:

«Y el que haze oración a Dios por medio de otro que de Iesu Christo, será oydo? - No. Antes pecca en orar assí. Porque no tiene mandamiento ni promessa de Dios para ello, y todo lo que no procede de fe es peccado. / ¿Luego los que inuocan a Dios por medio de los sanctos, que ya han passado deste mundo, son en lo mesmo offensores de su Magestad? - Es verdad, porque lo tiene Dios espressamente defendido, y muestra a los que assí lo hazen que no tienen a Dios por Padre ni conocen a Iesu Christo» (p. 158).

Se rechaza de plano cualquier oración que no sea por medio de Cristo, y, por consiguiente, muchas formas devocionales de los católicos. Pero queda claro el juicio severo que se hace, que no admite paliativos, hasta el punto de negarles la condición de hijos de Dios.

La segunda muestra elegida, de mayor agresividad, condensa otras del catecismo, sobre la negación del sentido sacrificial de la eucaristía, como defendían los católicos:

«¿Fue instituyda la Cena para que de nueuo se haga en ella sacrificio a Dios del cuerpo de su Hijo? - No, en ninguna manera, porque a solo Iesu Christo por ser eterno Sacerdote pertenece el officio de sacrificar, el qual en la cruz ofreció su cuerpo en perpetuo sacrificio, que bastó para nuestra salud. Y por tanto no resta sino que gozemos dél» (p. 160).

Vuelve a aparecer la misma enseñanza, adicionada con el duro calificativo de pecado, a propósito de la comunión con ambas formas en la tercera muestra seleccionada: 
« Y deue recebir todo Christiano la señal del pan y del vino, o basta vsar de la vna solamente? - Necessario es a todo Christiano recebir ambas a dos. Porque assí lo dexó ordenado y mandado el Señor Iesu Christo. Y el que haze contra esto, incurre en grauíssimo peccado» (p. 161).

La propuesta de la comunión es asumida como mandato y orden de Jesús, que no admite más que un cumplimiento sin condiciones.

Finalmente, la cuarta muestra de proposiciones expresadas con concisión y dureza es a propósito de quienes se acercan a comulgar sin fe:

«¿Y los que careciendo desta fe, se allegan a la Mesa del Señor para comulgar, que reciben? - Recibiendo el Sacramento del cuerpo y de la sangre del Señor, reciben juyzio y condenación contra sí, como dize san Pablo» (p. 162) ${ }^{44}$.

Con ello se previene la importancia de la fe, y el serio riesgo de carecer de ella, y llevar a cabo actos puramente externos.

Esta mayor dureza en las expresiones de Juan Pérez de Pineda, vertida en las preguntas añadidas al apéndice puede obedecer a dos causas; una ya la he apuntado: la de la concisión y brevedad; y otra, de índole pedagógica, el presentar las cosas a los niños que se acercaban por vez primera a la cena de forma muy nítida, e incluso exigente, para conseguir una actuación irreprochable por parte de ellos. Es verdad que el catecismo estaba dirigido también a los niños, pero el hecho de que el apéndice tenga unos destinatarios concretos, en una circunstancia particular pudo llevar a marcar con mayor claridad el nivel de exigencia, de forma que los niños no albergaran duda alguna. Pero no deja de ser llamativo que sea en las preguntas adicionadas por el traductor y corrector español las que tienen una mayor agresividad. Podría sospecharse otra razón que añadir a las apuntadas: la necesidad de mostrar sus convencimientos calvinistas, para que no quedara ningún asomo de duda.

\section{CONCLUSIÓN}

Las versiones castellanas del Catéchisme escrito por Calvino son fieles a él en su contenido, puesto que mantienen con exactitud las mismas preguntas, en el mismo orden, y con idéntica distribución (salvo el apéndice

\footnotetext{
44 Parecida a esta dificultad, que consta en la edición de 1559, en el apéndice, es otra que figura en el texto, por tanto en las dos ediciones examinadas, en la que pregunta por los que oran sin fe, o con dudas, cuyas «oraciones son del todo vanas y sin promessa alguna» (p. 76).
} 
sobre la cena). Se podría decir, sin problema, que es el pensamiento exacto de Calvino, vertido a otra lengua.

La diferencia es que la versión de 1550, más dependiente del francés, y menos dúctil, presenta el contenido con algunas expresiones complicadas, difíciles, o incluso imposibles en el castellano. El traductor confiesa que había perdido contacto de forma notable con su idioma materno, debido a su larga estancia en Ginebra, y esto queda patente en el escrito que salió de sus manos.

La otra versión, de 1559, resulta más elegante y ajustada al castellano. Se mueve incluso con cierta libertad, pues añade otros adjetivos, o sustantivos, e incluso alguna frase corta, a título de glosa, que no aparecía en el original. Sin embargo, consigue un escrito que se lee con mayor soltura. Esa misma libertad queda manifiesta en la carta inicial o prólogo, en que, como ha aparecido ya, retoma la carta primera de Calvino, pero la envuelve con sus pensamientos y reflexiones, sin ningún tipo de advertencia; y el resultado es un escrito preliminar amalgamado. Los apéndices que completan el catecismo son, en gran manera, reflejo de la evolución de las mismas ediciones francesas. De esta forma, el traductor, Juan Pérez de Pineda, mostró mayor soltura en el idioma, y una cierta capacidad de adaptación del catecismo de Calvino al público español al que se quería destinar. A la vez, en la carta al lector así como en el apéndice final, alteró el texto con una serie de añadidos y retoques en los que expresaba su sentir personal, más allá de lo que decía el catecismo.

Leídas hoy, desde la serenidad de los años, topamos con dos intentos para hacer difusión de la doctrina calvinista que aceptaron los huidos a Ginebra, desde donde trataban de comunicar su pensamiento a otros, a fin de que adoptaran su misma fe. 